INTER NATIONAL MONETARY FUND
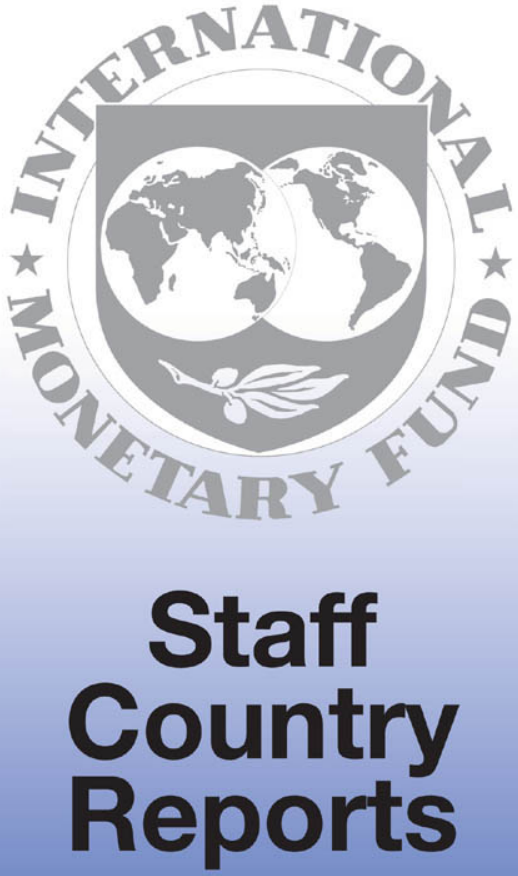


\section{United Kingdom: 2000 Article IV Consultation-Staff Report; Staff Statement; Public Information Notice on the Executive Board Discussion; and Statement by the Authorities of the United Kingdom}

Under Article IV of the IMF's Articles of Agreement, the IMF holds bilateral discussions with members, usually every year. In the context of the 2000 Article $V$ consultation with the United Kingdom, the following documents have been released and are included in this package:

- the staff report for the 2000 Article IV consultation, prepared by a staff team of the IMF, following discussions that ended on November 20, 2000, with the officials of the United Kingdom on economic developments and policies. Based on information available at the time of these discussions, the staff report was completed on February 2, 2001. The views expressed in the staff report are those of the staff team and do not necessarily reflect the views of the Executive Board of the IMF.

- a staff statement issued of February 23, 2001, updating information on recent economic developments.

- the Public Information Notice (PIN), which summarizes the views of the Executive Board as expressed during its February 23, 2001, discussion of the staff report that concluded the Article IV consultation.

- a statement by the authorities of the United Kingdom.

The document listed below will be separately released.

Selected Issues paper

The policy of publication of staff reports and other documents by the IMF allows for the deletion of market-sensitive information.

To assist the IMF in evaluating the publication policy, reader comments are invited and may be sent by e-mail to Publicationpolicy@imf.org.

Copies of this report are available to the public from

International Monetary Fund - Publication Services

700 19th Street, N.W. - Washington, D.C. 20431

Telephone: (202) 6237430 - Telefax: (202) 6237201

E-mail: publications@imf.org • Internet: http://www.imf.org

Price: $\$ 15.00$ a copy

\section{International Monetary Fund \\ Washington, D.C.}




\section{INTERNATIONAL MONETARY FUND}

\section{UNITED KINGDOM}

\section{Staff Report for the 2000 Article IV Consultation}

Prepared by Staff Representatives for the 2000 Consultation with the United Kingdom

Approved by Jacques R. Artus and Leslie Lipschitz

February 2, 2001

- The Article IV consultation discussions took place in London during November $9-20,2000$.

- The mission met with the Chancellor of the Exchequer, the Governor of the Bank of England, and other senior government officials, including members of the Monetary Policy Committee and officials of the Financial Services Authority. Staff also met with private sector groups including representatives of the Trade Union Congress, the Confederation of British Industries, private think tanks, retail and investment banks, and venture capital groups.

- The mission comprised Mr. Artus (head), Ms. Coorey, Mr. Escolano, Ms. Kodres. Mr. Ubide (all EUl) and Mr. Prasad (RES). Mr. Pickford, Executive Director for the United Kingcom participated in the discussions.

- The United Kingdom has accepted the obligations of Article VIII, Sections 2, 3, and 4 . The exchange system is free of restrictions on the making of payments and transfers for current international transactions (Appendix II).

- The United Kingdom has subscribed to the Special Data Dissemination Standard (SDDS) (Appendix III).

- The authorities released the mission's concluding statement and have agreed to the publication of the staff report. 
Executive Summary 4

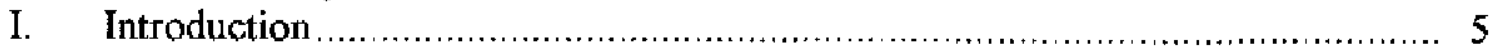

II. Setting for the Discussions.

A. Economic Background

B. Policy Developments

III. Policy Discussions. 10

A. The Economic Conjuncture and Short-Term Policy Issues ............... 10

B. Medium-Term Issues

IV. Staff Appraisal. 22

Text Boxes

1. Potential Output and the NAIRU 26

2. What's So Special About This Cyclical Expansion? A New Perspective from Labor Market Data 27

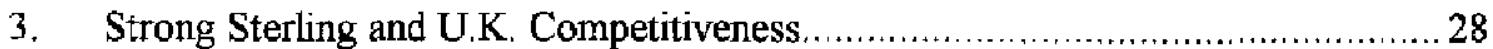

4. So Where is the "New Economy" in the United Kingdom? ..........................29

5. Financial Sector Risks and Vulnerabilities .................................................. 30

Tables

1. Selected Economic Indicators ............................................................ 31

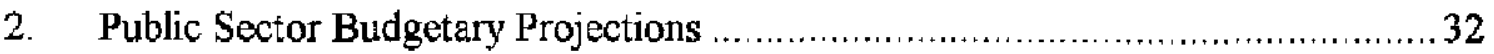

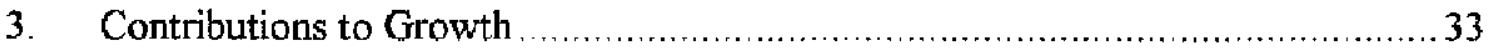

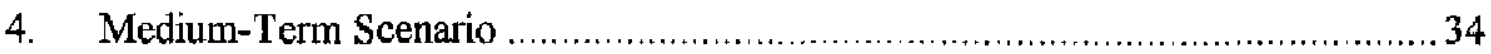

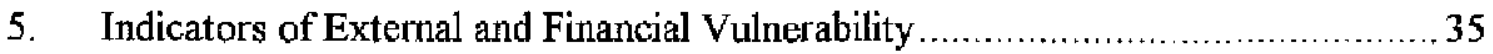

Figures

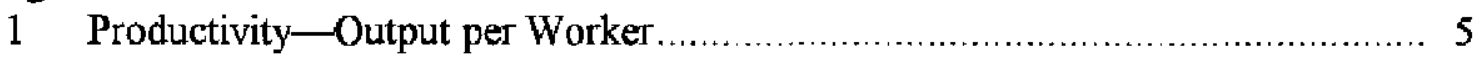

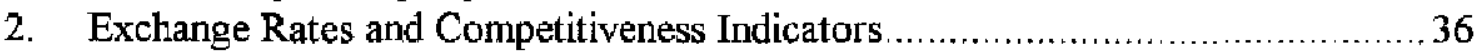

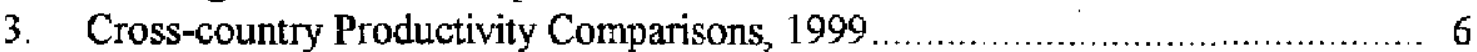

4. Expenditure Contributions to Quarterly Growth of GDP ............................. 37

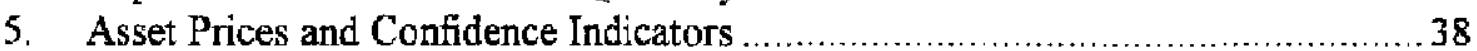

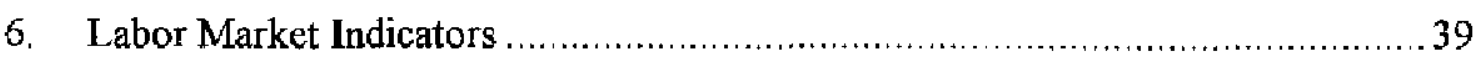

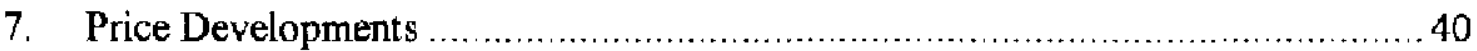

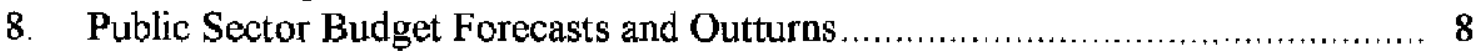

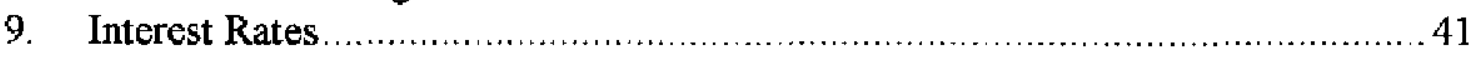

10. Three-Month Actual and Implied Forward Interest Rates .............................. 10

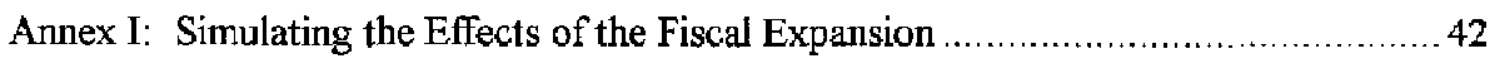

Appendices

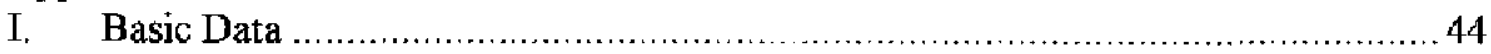




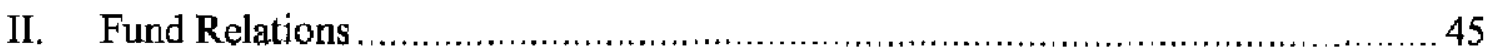

III. Statistical Information .............................................................................. 46 


\section{Executive Summary}

Background: The United Kingdom is experiencing the longest period of sustained noninflationary output growth in more than 30 years, partly owing to strengthened macroeconomic and structural policies underpinned by improved monetary and fiscal policy: frameworks. The productivity performance of the United Kingdom economy, however, has been weak. Output grew briskly in 2000 with private consumption being the main driving force. Net exports continued to exert a substantial drag on growth due to a loss of external competitiveness. Unemployment fell further and earnings growth decelerated through the year while inflation remained subdued. The $1999 / 00$ budget closed with a substantial overperformance, but budget policies envisage sizable spending increases. The Bank of England has kept policy rates unchanged at 6 percent since February 2000

Short-term policy issues: The discussions focused on whether the ongoing fiscal expansion risked accentuating overvaluation and overheating pressures. While the risks to the outlook appeared balanced at the time, downside risks from a sharper U.S. slowdown have increased since then. The staff noted that the planned expansion in public spending, while sustainable, posed short-term risks. Staff argued that the 2001 budget refrain from substantial new spending commitments or tax cuts beyond those already announced. The authorities, however, did not consider their budgetary plans expansionary as they aimed to correct past fiscal overperformance and return the fiscal balances to the previously announced path, consistent with the fiscal rules. On monetary policy, staff agrees there has been no pressing need thus far to cut the policy rate. However, the authorities will need to stand ready to cut rates if wage moderation persists and downside risks, particularly from a deteriorating external outlook, materialize.

Medium-term policy issues: The authorities' medium-term fiscal strategy seeks to increase public spending on priority areas while maintaining a sound budgetary position. Staff broadly agreed with this strategy but suggested that there was, on the margin, scope to enhance the public sector contribution to national savings and investment by using the likely future revenue overperformance to run a broadly balanced budget over the cycle. Staff noted that this would not imply a change in the current three-year Departmental Expenditure Limits, only that no significant new (i.e, previously unannounced) budget initiatives be introduced that would whittle down each year's overperformance. The authorities noted that their budget projections were deliberately cautious, but were skeptical of some of the staff's arguments.

An analysis of the United Kingdom's New Economy suggests sizable information and communications technology (ICT) investment and productivity gains in the ICT sector, but very low productivity growth in the rest of the economy. The authorities' policies to promote innovation, R\&D, competition, and entrepreneurship will contribute to raising productivity. Staff noted that strengthening the education system and improving skill levels were also clear priorities. Progress had been made with regard to pension reform, but some caution may be needed on any further public pension commitments. The banking sector continued to show strong profitability and capitalization, but the authorities remained vigilant of possible vulnerabilities in the current riskier environment, particularly regarding exposures to the telecommunications sector and the increased indebtedness of households and corporations 


\section{INTRODUCTION}

1. The United Kingdom is experiencing the longest period of sustained noninflationary output growth in more than 30 years. Output has grown at an annual average of 2.9 percent during 1993-2000, the rate of unemployment is at its lowest level in a quarter century while inflation has remained at or below 3 percent. The flexibility of the economy has increased, particularly with respect to labor and capital markets, which augurs well for the economy's capacity to adjust to external shocks, a particularly important consideration for an economy as open as that of the United Kingdom. Long-term interest rates have declined markedly anc private investment has increased, reflecting declining risk premia and improved business confidence.

2. These substantial gains are due in no small measure to strengthened macroeconomic and structural policies underpinned by improved monetary and fiscal policy frameworks. Private sector confidence in fiscal policy has greatly benefited from the marked tightening of the late 1990 s and the new transparent, medium-term oriented fiscal framework. "The conduct of monetary policy improved with the adoption of inflation targeting in 1992 and the introduction of a strong monetary policy framework with the granting of operational independence to the Bank of England in 1997. Structural reforms and deregulation which began a decade and a half ago have also contributed to sustained employment growth and a well-functioning labor market as well as more competitive product and capital markets.

3. Despite these achievements, areas of weakness remain, most notably the United Kingdom's productivity performance in comparison with other major industrialized countries. Labor productivity growth of the whole economy languished in the second half of the 1990s at below the long-term trend of 2 percent per annum (Figure 1).

Manufacturing productivity fell at an average annual rate of 0.3 percent in $1995-1998$ and contributed to a marked decline in external competitiveness (Figure 2). Recent studies show that in 1999, the United Kingdom's labor productivity stood well below those of its main trading partners (Figure 3 ). The

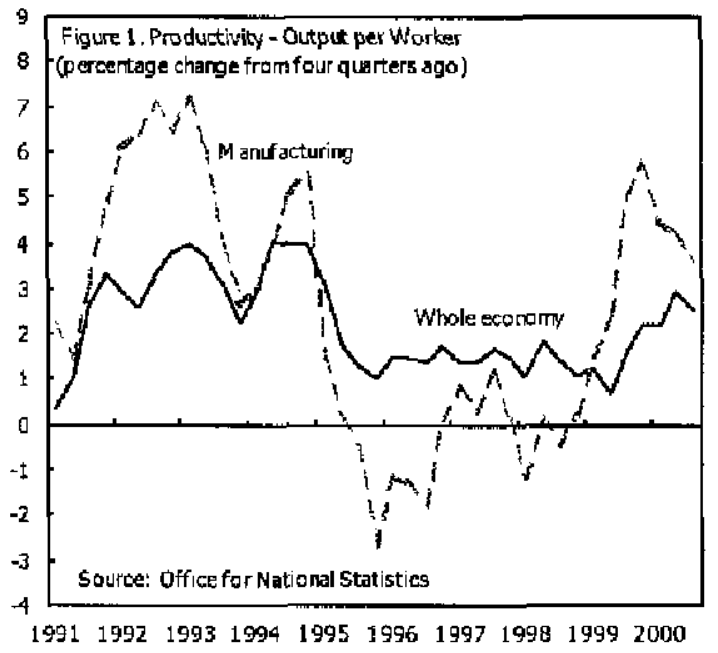

\footnotetext{
${ }^{1}$ The fiscal and monetary frameworks are discussed in greater detail in the staff reports for the 1998 and 1999 Article IV consultations (SM/99/36, 2/10/1999 and SM/00/28, 2/9/2000).
} 
differential can be attributed to both lower physical capital in the private and public sectors, reflecting past underinvestment, and to lower total factor productivity (TFP) partly due to skill deficiencies in the labor force. ${ }^{2}$ While the pickup in productivity since the middle of 1999 is encouraging, achieving a sustained and broadbased increase in productivity growth remains a key challenge for both the public and private sectors.

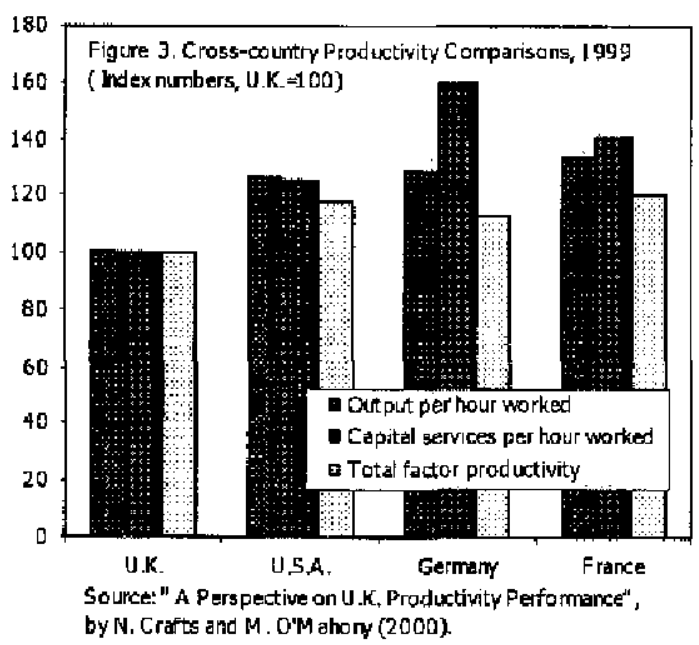

4. Against this background, this staff report addresses two broad themes:

- Given the current economic conjuncture, are short-term fiscal and monetary policies appropriate to the task of maintaining macroeconowic stability with a reasonable exchange rate?

- Given the weak productivity performance, are policies and reforms with regard to the medium-term public finances, competition and innovation, labor markets, pensions, and the financial sector sufficiently ambitious?

5. At the conclusion of the last consultation on March 1, 2000, Directors commended the authorities for the United Kingdom's impressive economic performance over much of the 1990's. They observed that the short-term risks were now mainly on the upside and that the main challenge was to prevent overheating, even if the immediate prospects for inflation remained benign. While noting the Bank of England's record in taking timely preemptive action, most Directors agreed that monetary policy would likely need to be tightened further over the course of the year. Given cyclical considerations and the strong real exchange rate, Directors stressed the need for the fiscal stance to remain supportive of monetary policy. They urged that the March 2000 budget preserve the margins built up by the overperformance during the previous year.

\footnotetext{
${ }^{2}$ A detailed analysis of the United Kingdom's productivity performance and its causes is provided by N. Crafts and M. O'Mahony "A Perspective on UK Productivity Performance" National Institute for Economic and Social Research, Mimeo, 2000. Labor productivity growth is determined by both capital deepening-that is, increases in capital stock per worker-and TFP growth. TFP reflects productivity not attributable to the inputs of capital and labor and is often viewed as the technological or organizational components of labor productivity growth.
} 


\section{SETTING FOR THE DISCUSSIONS}

\section{A. Economic Background}

6. Output has grown briskly during the past year and a half, fueled by buoyant domestic demand. GDP growth in 2000 is estimated at 3 percent (Table 1). Private consumption has been the main driving force, reflecting employment gains throughout the period and sizeable increases in real earnings, disposable income, and wealth in 1999 and early-2000 (Figure 4). Although earnings growth has subsequently decelerated and bousing and stock market prices have plateaued, consumption growth so far has shown little sign of slowing (Figure 5). The growth of private gross fixed capital formation has weakened after the high rates reached in 1998-99, but real business investment as a share of real GDP remains relatively high. Net exports continued to make a sizeable negative contribution to growth, reflecting the strength of domestic demand and the loss of external competitiveness. The preliminary estimate for GDP in the fourth quarter (only 0.3 percent) suggests that the economy's momentum may now be slowing, although temporary factors may have been at play (e.g., unusually weak oil and gas extraction and downward effects from flooding and transport disruptions).

7. After several years of lackluster performance, labor productivity growth of the whole economy picked up starting in mid-1999, reaching an annual growth of 2.6 percent in the third quarter of 2000 . The rebound was particularly marked in manufacturing, but has as yet been uneven, being led by a few sectors such as electrical and optical equipment, engineering, and chemicals. Productivity gains in these high tech industries as wefl as in the business service sector, which is a heavy user of information and communication technology (ICT), has sparked interest in possible "New Economy" effects.

\section{Unemployment has reached low levels and lahor market conditions have} tightened. The unemployment rate (on a labor force survey basis) declined to 5.3 percent in September-November from 5.9 percent a year earlier (Figure 6). Earnings growth decelerated to 4.4 percent in November from a beginning-year peak of 6.3 percent which reflected some one-time millennium-related effects on bonuses. However ${ }_{2}$ pay settlements, a measure more indicative of underlying wage trends but with substantially less coverage than earnings, has remained broadly stable at around 3-4 percent. With the improved productivity performance, the growth in manufacturing unit labor costs has decelerated to 0.8 percent in the three months to November from 4.1 percent two years ago.

9. Inflation has remained subdued, reflecting the strength of sterling, favorable labor market developments, and declining retail margins due to competitive pressures. The inflation rate (RPIX, which excludes mortgage interest payments) has hovered around 2 percent since mid-1999 while the harmonized index of consumer prices (HICP) has been at 
one percent or less during 2000, the lowest in the EU (Figure 7). It appears that most of the first-round effects of the increase in crude oil prices since end-1998 have been passed through with little adverse effects on overall prices.

10. Sterling remained at high levels in both nominal and real effective terms during 2000, but thanks partly to the United Kingdom being on balance a net exporter of oil, the deterioration in the external current account appears to have leveled out. Despite the deceleration in the growth in manufacturing unit labor costs, competitiveness vis-à-vis trading partners has continued to deteriorate in 1999-2000 (see Figure 2). Exports have coped surprisingly well, with non-oil export volumes standing 11 percent higher in the first eleven months of 2000 over the year before, buoyed by rising external demand. However, imports have also risen rapidly with the result that the current account deficit has remained in the range 1.3-1.5 percent of GDP during the first three quarters of 2000 .

\section{B. Policy Developments}

\section{Fiscal Policy}

\section{The FY1999/00 budget closed with an overperformance of more than two} percentage points of GDP, but budget policies envisage sizeable spending increases in $\mathrm{FY}$ 2000/01 and beyond (Table 2). ${ }^{3}$ The strong outturn in 1999/00 reflected buoyant revenue collections party due to a faster-than-expected turnaround in economic activity, tax reforms enacted in earlier budgets, lower interest costs and cyclical spending, and delays in the execution of investment plans. The March 2000 Budget and the July Spending Review introduced a frontloaded increase in expendituremainly in public investment and other programs covered under the three-year Departmental Expenditure Limits (DELs) ${ }^{4}$--that would lower the overall balance by over 1 percent of GDP to a

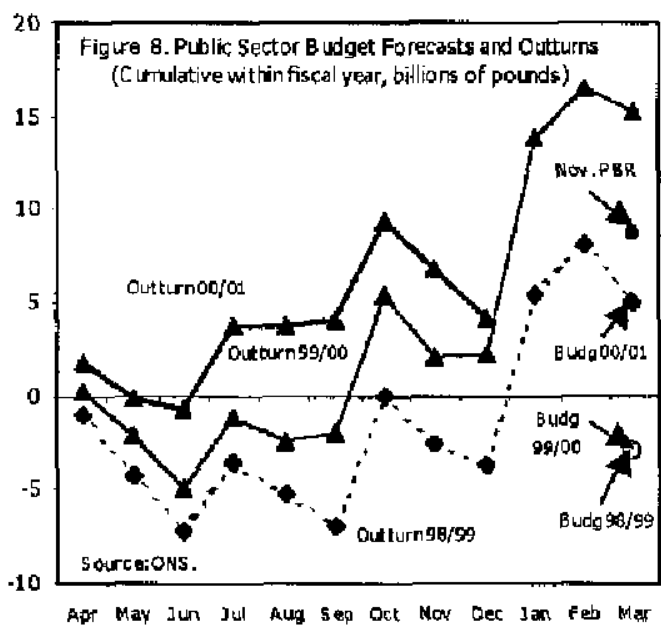
surplus of about 0.5 percent of GDP in 2000/01 and

${ }^{3}$ The fiscal year starts on Aptil 1 and runs through end-March the following calendar year

4 Total Managed Expenditure constitutes the total of public spending. About half-including most investment programs and current expenditure that can be planned in advance-are included in the DELs which are set in nominal terms for the three years through bi-annual spending reviews. The first Comprehensive Spending Review was in 1998 and laid out spending plans for 1999/00-2001/02; the second took place in July 2000 and covered 2001/02-2003/04. The rest of public spending, including cyclical and unpredictable expenditures and interest payments, constitutes Annually Managed Expenditure, which is budgeted annually. 
to a deficit of one percent of GDP by 2003/04 (on the basis of official projections). The November Pre Budget Report (PBR) used part of the overperformance in 2000/01 (reflecting lower interest and transfer payments as well as an apparent structural increase in revenue) to expand Annual Managed Expenditure (AME) through enhanced pensioner benefits, a fuel tax freeze, and possible fuel excise rate cuts that were proposed for consultation. A comparison of budget execution to date with that of earlier years suggests, however, that the budget outturn in 2000/01 is still likely to exceed the PBR projections by almost $1 / 2$ percentage point of GDP (Figure 8), as PBR revenue projections remain conservative and there appear to be delays in implementing the spending increases. ${ }^{s}$

12. No major tax initiatives were introduced in the $1999 / 00$ and $2000 / 01$ budgets, but revenue developments indicate improvements in the efficiency of the tax system stemming from prior tax policy and tax administration reforms. Revenue in $2000 / 01$ has been boosted by high income tax collections, excises, and direct taxes on oil. For several years, tax buoyancy has exceeded not only budgetary projections, which are deliberately biased downwards for reasons of prudence, but also neutral estimates of cyclical effects. Changes to the tax system appear to have increased effective tax rates by enhancing compliance, reducing tax avoidance, and expanding the statutory tax base. These changes include self-assessment for the self-employed, phased-in replacement of the Advance Corporate Tax by a standard system of advance corporate income tax payments based on quarterly profit estimates, and elimination and simplification of some deductions and allowances such as mortgage costs. As a result, staff estimates that the cyclically-adjusted tax-to-GDP ratio has risen further, from 36.5 percent in $1998 / 99$ to an estimated 37.5 percent in $2000 \% 1$.

\section{Expenditure policies focused on increasing allocations for public investment,} health, education, social services, and law enforcement, with the overall aims of increasing productivity and improving the quality and volume of public services. Gross public investment, which had declined to a historically low level of 2 percent of GDP in $1999 / 00$ partly reflecting the fiscal adjustment of the $1990 \mathrm{~s}$, is now set to increase to 3.3 percent of GDP by $2004 / 05$ (Table 2). Real total public spending is envisaged to increase by 5.7 percent in 2000/01 and by 3.1 percent per annum on average in 2001/02-2003/04. In the latter period, the most significant departmental increases, in real annual average terms, are in infrastructure investment (12.6 percent), ${ }^{6}$ education and training ( 5.4 percent), and health, including the National Health Service ( 6.5 percent).

\footnotetext{
${ }^{5}$ The spending delays partly reflect the usual implementation lags in increasing public spending as well as various administrative safeguards built in to ensure the cost-effectiveness of public spending.

${ }^{6}$ The increase in the budget of the Department of the Environment, Transport and Regions.
} 


\section{Monetary Policy and Interest Rate Conditions}

14. The Bank of England has kept policy rates on hold at 6 percent since February 2000 following a 100 basis point tightening cycle that started the previous summer. For much of the year, the Monetary Policy Committee (MPC) was narrowly divided over the need for further rate increases. However, with the continued moderation in wage and inflation pressures and indications that factors underpinning private spending may be weakening, views shifted later in the year with the decision to keep rates unchanged being unanimous or supported by a clear majority. At the same time, as evidenced by the November Inflation Report, the uncertainty bands around the Committee's inflation forecast have widened, with the key issues being: (i) the likelihood of wage pressures; (ii) the pace of deceleration of private sector demand; and (iii) the speed of the slowdown in the world economy, and (iv) the evolution of oil prices.

\section{As inflation pressures turned out surprisingly moderate and concerns about} possible overheating dissipated, initial market expectations of further official rate rises faded. Sterling money market rates fell steadily during the year, easing monetary conditions, particularly at the two-year maturity which is generally regarded as having a greater impact on domestic demand in the United Kingdom (Figure 9). The yield curve became gently downward-sloped as longer maturity yields also declined. With recent evidence pointing to a moderation in economic activity and a weaker external environment, and many MPC members voting for a rate cut in January, the market appears to be pricing in about a 50 basis point decline in short-term interest rates in 2001 (Figure 10).

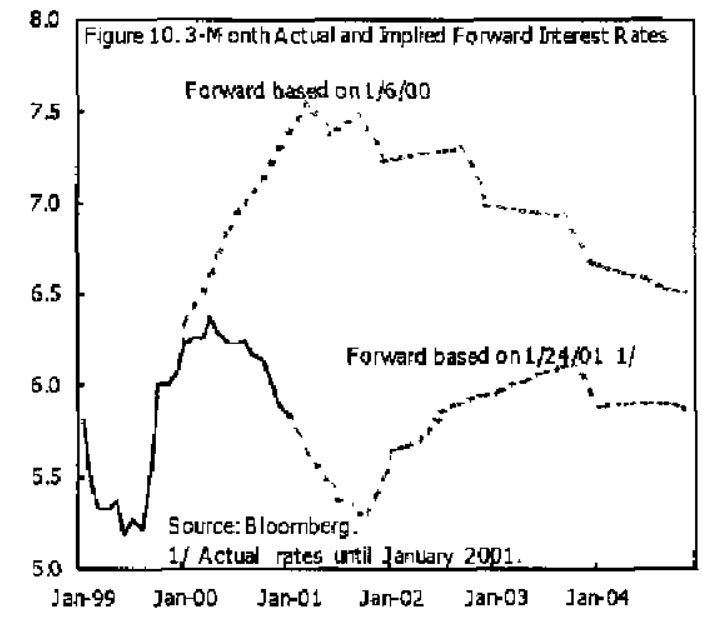

\section{POLICY DISCUSSIONS}

\section{A. The Economic Conjuncture and Short-Term Policy Issues}

16. The discussion on demand management focused on the short-term prospects for the economy, and whether the ongoing fiscal expansion risked generating overvaluation and overheating pressures down the road. These discussions were conditioned by the assessment of risks to the economic outlook and increased uncertainty over the projections, the economy's cyclical position, and the extent of sterling overvaluation. While upside and downside risks appeared to be balanced at the time of the discussions, downside risks, particularly from a sharper slowdown in the United States, have increased since then. 


\section{Short-Term Economic Outlook}

17. The staff and the authorities were in broad agreement over the short-term outlook, which is also in line with most private sector forecasts. Government projections envisaged GDP growth in the range of $2 \frac{1 / 4-23 / 4}{4}$ percent in 2001. Staff expected GDP to grow at $2 \frac{3}{4}$ percent with the economy maintaining a healthy pace of growth as the surge in public spending offsets a moderation in private domestic demand after four years of strong growth (Tables 3 and 4). Private consumption growth is projected to decelerate as asset prices stabilize, earnings growth remains moderate, and--given high levels of household debtconsumers increase saving to rebuild their net asset positions. Private investment growth is expected to remain flat, reflecting already high levels of corporate indebtedness, low investment intentions, and strong sterling. Increased government spending, in line with projections in the PBR, is expected to contribute over l percentage point to GDP growth. The external sector will continue to exert a drag on growth, as the export expansion slackens in the face of weaker external demand conditions.

18. There were no significant differences between the staff's and authorities' views on the cyclical position of the economy. The government estimated that output passed potential in mid-1999 with GDP in 2000 standing some 0.5 percent above potential GDP. The staff's analysis suggests an output gap close to zero in 2000. ${ }^{7}$ However, given the range of uncertainty surrounding these estimates, the staff concurred with the authorities' view that the economy was now operating in a zone where it was especially necessary to watch carefully for signs of emerging wage and price pressures

19. At the time of the discussions, the risks to the outlook were balanced, with the possibility that stronger-than-anticipated private demand might push output above potential, creating overheating risks, and a weaker-than-expected external environment might do the reverse; however, the risk concerning the external environment has increased somewhat in recent weeks. An upside risk to the forecast is that private spending may not slow down to the extent projected. Household disposable income is envisaged to grow briskly at 3-31/4 percent and, although asset prices have weakened, household borrowing -including mortgage equity withdrawal and consumption credit-remains strong while borrowing by non-financial companies is still growing rapidly. On the downside, there may be a more pronounced deterioration of the external outlook or financial market turmoit than anticipated, particularly from sharper-than-expected slowdown in the U.S. economy. The repercussions for the United Kingdom of such a deterioration are difficult to gauge: although

\footnotetext{
${ }^{7}$ Staff's work, based on an econometric exercise that controls for various supply side shocks, suggests a decline in NAIRU to about 5.5 percent in 2000, the same level as the actual unemployment rate (Box 1). Further analysts based on individual-level data in the New Earnings Survey also indicates that so far there are no hidden wage pressures (Box 2). See also the accompanying Selected Issues paper "What's So Special About This Cyclical Expansion in the United Kingdom? A New Perspective from Labor Market Data."
} 
the direct effects through trade would be limited, there could be larger effects on domestic demand through capital flows and a deterioration of business and consumer confidence, particularly given the importance of financial services. ${ }^{89}$ Since output is now close to potential, if upside risks prevail, stronger-than-anticipated growth would push output above potential with inflation tending to rise, while if downside risks prevail, weaker growth could result in declining inflation.

20. The extent of possible sterling overvaluation is also an important consideration going forward. ${ }^{10}$ Staff analysis of the real exchange rate based on a macroeconomic balance approach suggests that on a multilateral basis sterling appears overvalued, with a marked overvaluation against the euro offset only partly by an undervaluation against the U.S. dollar. ${ }^{11}$ This view, is broadly supported by a more qualitative analysis of the possible effects of strong sterling on U.K.'s competitiveness. ${ }^{12}$ Following an initial sharp contraction in export growth, firms appear to have adapted in recent quarters by increasing productivity (Box 3). High technology, high value added exports in particular, appear to have fared better than traditional exports such as crude materials, food, clothing, and material manufactures, suggesting that exports have become more resilient through structural shifts within

${ }^{8}$ The United States accounts for about 15 percent, and the European Union for about 60 percent, of total U.K. exports. A simulation of the Oxford Economic Forecasting (OEF) model of a hard landing in the United States, shows a limited impact on the U.K. economy, although this does not fully reflect confidence and capital flow effects: if U.S. growth slows to zero quarter-on-quarter growth in the first two quarters of 2001, U.K. GDP growth is reduced by 0.4 percentage points in $200 \mathrm{I}$, with U.K. equity prices falling by 15 percent.

${ }^{9}$ A smaller-than-anticipated decline in the price of oil could also be a downside risk, but the net impact is likely to be small because of offsetting effects on the oil producing sector and oil consuming sectors. Simulations of the OEF model and Multimod of a US\$5 per barrel increase in the price of oil show a decline in GDP of about $0.1-0.3$ percent in each of the first two years and an improvement in the current account of about 0.2 percent of GDP. RPIX inflation increases by $0.2-0.3$ percent in the first year and by $0.1-0.2$ percent in the second year.

${ }^{10}$ The reference period for this assessment is January 1-15, 2001 at which time the nominal exchange rate stood at US\$1.49 and €1.58 (equivalent to DM3.1).

${ }^{11}$ For a discussion of the underlying methodology, see P. Isard and H. Faruque "Exchange Rate Assessment: Extensions of the Macroeconomic Balance Approach" Occasional Paper No. 167.

${ }^{12}$ See "Strong Sterling and the United Kingdom's External Competitiveness" in the accompanying United Kingdom -Selected Issues volume. 
manufacturing. However, import penetration has increased sharply and investment expectations, which appear negatively correlated with the real exchange rate, have declined. The broad picture that emerges is one where firms appear to be adapting to a higher exchange rate, but where overvaluation-if it persists at current level or worsens-could have negative consequences for investment and growth.

\section{Short-Term Fiscal Policy}

\section{Given the foregoing assessment, the staff noted that the magnitude of the} planned expansion in public spending during the second half of 2000/01 and in 2001/02 was not without risks. Staff agreed that given the budget surplus and a rapidly declining debt to GDP ratio, the proposed fiscal path did not threaten sustainability and was fully consistent with the Government's medium-term fiscal framework. Nevertheless, the envisaged adjustment of expenditures to the medium-term fiscal path was fairly rapid, amounting to a cumulative spending increase of about $10 \%$ percent in real terms and a fiscal impulse of some 1.3 percent of GDP in 2000/01-2001/02 (including likely underspent allocations carried over from one year to the next; see Table 2). Following a subdued level of spending in 1999/00 and spending delays in the first half of 2000/01, this could impart a sizeable boost to domestic demand in 2001/02, at a time when resource utilization was expected to remain high and the real exchange rate overvalued. If domestic private spending and external demand remained strong, the fiscal impulse would contribute to pressures for an interest rate increase and possible further real appreciation. If the downside risks coming from abroad were to prevailand these risks have increased in the past few weeks - fiscal policy would limit the room to cut interest rates in 2001 , at a time when interest rates would decline markedly in the United States and to a lesser extent in the euro area. Again this could worsen the overall exchange rate overvaluation and work against the convergence of sterling to a sustainable rate vis-à-vis the euro. In light of these considerations, staff suggested that it would be prudent for the March $200 \mathrm{I}$ budget-an election-year budget-to refrain from new spending commitments or substantial tax cuts that would increase the fiscal impulse above that already envisaged.

\section{The authorities did not agree that fiscal policy was expansionary. First, they} stressed that the path for the structural fiscal balance through $2003 / 04$ was more or less unchanged from the prudent course announced in the 1999/00 budget; and second, that given the likely lags in the effects of fiscal policy on activity, the spending increases budgeted for $2000 / 01-2001 / 02$ would still be offset to some extent by the contractionary effect on demand stemming from the fiscal overperformance in 1999/00. Under their framework, fiscal policy was set in each budget on a medium-term basis and within the fiscal rules. Their medium-term fiscal plans allowed for much-needed increases in government spending on public services and public investment within a sustainable path for the overall fiscal balance. ${ }^{13}$ Since this medium-term path was more or less unchanged by the 2000 budget announcements, there would be minimal effects on private sector expectations and hence on

${ }^{13}$ Medium-term fiscal issues are discussed below in paragraphs 29-32 in greater detail. 
private sector behavior. Furthermore, the sharpness of the envisaged increase in spending was only the counterpart of the preceding fiscal tightening, the lagged effects of which were still unraveling. With regard to the March 2001 budget, the authorities noted that their latest proposals had been set out for consultation in the November PBR and that they would be formulating specific policies-which would be consistent with the fiscal framework-closer to the time of the budget.

23. Staff considered that the budget plans for $2001 / 02$, even though announced well ahead of time, would still have an expansionary effect on demand, while the lagged impact of earlier fiscal contractions was likely to have tapered off for the most part by then. Even if the envisaged spending increases did not come as a surprise to the private sector because the medium-term fiscal deficit was not significantly larger than announced in the 1999/00 budget, it was difficult to argue-except from an extreme Ricardian standpoint--that private demand would automatically contract to accommodate this expansion. Most of the empirical literature in this area rejects this view on the grounds that government consumption is more a complement to household consumption than a substitute and that a significant fraction of national income accrues to liquidity-constrained households. ${ }^{14}$ The lack of substitutability with respect to private consumption is likely to be particularly pronounced in the case of spending on public goods such as infrastructure or law enforcement-some important areas of spending increases in the 2000 budget decisions. Regarding lags in fiscal policy, staff noted that the offsetting effects of tight fiscal policy in $1999 / 00$ may have been a factor in 2000/01, but were unlikely to have much residual impact in 2001/02. Illustrative model simulations, which take into account the lagged effects of fiscal policy on domestic demand, suggest that a fiscal expansion of roughly the timing and magnitude envisaged could have a significant expansionary effect in 2001 (Annex I).

\section{Monetary Policy}

\section{Staff supported the decision of the Monetary Policy Committee to keep rates on}

hold. In the first part of 2000 , resilient private consumption growth, rapid credit expansion, and tightening labor market conditions (as indicated by quantity indicators) suggested possible overheating risks further down the road. However, subdued wage and price pressures reflecting the likely sharp decline in the structural rate of unemployment and the temporary effects of sterling appreciation militated against a preemptive rate increase and supported the case for keeping rates unchanged. MPC members indicated, in this connection, that they had not felt a need to raise rates in response to the 2000 budget announcements partly because

${ }^{14}$ See, for example, P. Evans and G. Karras (1996), "Private and Government Consumption with Liquidity Constraints," Journal of International Money and Finance, Vol. 15, No. 2, pp. 255-266. They find that, in the United Kingdom, about 79 percent of national income accrues to households that behave as if liquidity constrained (i.e. unable to borrow for current consumption to a level consistent with their lifetime income) and that public consumption is highly complementary to private consumption, with both results strong by international standards and statistically significant. 
expenditure measures were largely offset by the higher-than-expected revenue performance. They noted that a key question in this regard was whether the revenue gains would prove to be permanent.

25. Staff noted that a continuation of unchanged interest rates seemed appropriate for the time being, but policy makers needed to stand ready to move flexibly in either direction depending on how the risks play out. Inflation and wage pressures continued to be moderate and the fiscal expansion most likely would not create significant overheating risks if private spending decelerated as expected, although it would still contribute to keeping the exchange rate elevated. Interest rate action would also need to await a reliable assessment of the likely impact on the U.K. economy of the slowdown in the U.S. economy and the recent U.S. rate cut. Looking forward, given the broadly balanced risks to the outlook and the symmetry of the inflation target, the next rate change could be in either direction. If private spending did not slow down as expected or wage settlements pick up excessively in early 2001, a rate increase could be needed. On the other hand, if the external environment deteriorated further or domestic demand weakened by more than anticipated, the case for a rate cut would be strengthened.

26. Given the uncertainty-over the cyclical position of the economy and the global outlook-discussions touched on the implications of greater uncertainty for the conduct of monetary policy. Members noted the importance of distinguishing between different kinds of uncertainty, rather than endorsing a blanket "wait and see" approach. In the case of uncertainty over the current level of potential output and the cyclical position, some members felt that the economy's capacity for noninflationary expansion should be "probed" by lowering rates or at least keeping them unchanged. Members also observed that in other circumstances, it may be appropriate to hold off on interest rate action--for instance, situations where uncertainty stemmed from noisy data (e.g., the recent fuel protests, public transport problems, inclement weather) or where data that could help resolve the uncertainty would soon become available. By contrast, when the uncertainty was not of a kind that would be resolved in the foreseeable future-e.g. uncertainty over the future growth of potential output-it would be necessary to act according to one's best judgment. The mission concurred with these arguments, including those in favor of "probing" the limits of noninflationary expansion, but noted that policy should also respond speedily to signs of cost and price pressures.

\section{In the period since the discussions took place, the MPC has twice voted to keep} the policy rate unchanged, but the debate has shifted to whether the policy stance should be maintained or eased. In the minutes of the December and January meetings, although members agreed that the downside risks from the weakening U.S. and global outlook had increased, they differed in their assessment of the likely impact on the U.K. economy and equity markets. Furthermore, some members noted that there was little sign of consumption slowing to the extent needed and that risks of wage pressures remained, while others noted the weaker investment growth and supported a preemptive rate cut to help sustain confidence given the limited risks of jeopardizing achievement of the inflation target. Staff agrees that there was no pressing need to cut interest rates. However, given the extent of the slowdown in the United States and the possible direct and indirect effects on the U.K. 
economy, as well as the lack of wage/price pressures, the monetary authorities should not hesitate to cut interest rates if signs of weakening economic activity emerge

\section{B. Medium-Term Issues}

28. Medium-term macroeconomic and structural policies are key to attaining the Government's objective of high and stable levels of output and employment growth, an essential element of which is the achievement of higher productivity growth. The Government's strategy in this regard is multi-faceted, and rightly so, given the many factors driving these variables. Policy frameworks have provided a medium-term focus particularly to fiscal policy, clarifying the role of the public finances in fostering investment and productivity growth. Structural policies have aimed at both further increasing employment and strengthening the productivity performance-the latter of which will be key to raising output growth in the medium term given the increasingly limited possibilities for continuing a mainly employment-based expansion as the economy approaches full employment.

\section{The Fiscal Framework and Medium-Term Fiscal Policy}

29. The authorities stressed that their medium-term fiscal strategy seeks to increase public spending on investment and other priority areas while maintaining a sound budgetary position. The fiscal framework comprises three main elements: (i) two fiscal rules; (ii) announced medium-term budget plans; and (iii) a regime for planning and controlling spending intended to enhance the accountability of government departments and the costeffectiveness of public expenditure. ${ }^{15}$ The fiscal rules, which are defined over the business cycle, are: ${ }^{16}$ (i) the golden rule which stipulates that the government will borrow only to invest and not to fund current spending, hence precluding deficits on the current balance; and

(ii) the sustainable debt rule which stipulates that public sector net debt as a proportion of GDP will be held at a stable and prudent level (currently interpreted as not exceeding 40 percent of GDP). The authorities noted that the spending increases in their budget plansmainly on public investment, health, and education-were intended to fulfill the government's mandate to improve the quality and quantity of public services and to partially correct the short fall in the public capital stock. The overall balance is projected to shift over the medium. term from surplus to a deficit of about 1 percent of GDP (see Table 2). These plans fall well within the two fiscal rules, with the current balance in surplus and the net public debt ratio projected to decline to 31 percent of GDP by 2004/05-well below the prescribed ceiling.

30. The staff broadly agreed with the authorities' medium-term strategy, particularly the need to enhance public infrastructure and human capital while maintaining a sound overall fiscal position. The priority placed on education and investment was well founded, given the strong fiscal position and evidence that the United

${ }^{15}$ The fiscal framework was discussed in greater detail in SM/99/36 and SM/00/28.

${ }^{16}$ See, for example, “Analysing UK Fiscal Policy," HM Treasury, November 1999. 
Kingdom's weak productivity performance was partly attributable to inadequate public infrastructure and skill deficiencies. Staff also noted, however, that the levels of U.K. public spending on education were comparable to those of continental European countries suggesting the need for reforms aimed at specific weaknesses - for instance, the relatively low levels of basic and intermediate skills-rather than just higher spending (see paragraph 36 below). Staff was also broadly supportive of the authorities' fiscal framework which had underpinned a sizeable fiscal consolidation and provided a medium-term orientation to fiscal policy and increased transparency.

\section{The mission suggested that there was, on the margin, scope to enhance the} public sector contribution to national saving and investment, and thereby to productivity growth. Given the built-in caution in the authorities' budget projections, revenues were likely to overperform over the medium-term, as they had done in the past few years. There appeared to be a tendency to use this overperformance to raise spending and to introduce somewhat piecemeal tax breaks. Staff suggested that it would be better to use any future revenue overperformance to run a broadly balanced budget over the cycle ${ }_{7}$ i.e, to fund public investment through public saving on current balance rather than through borrowing. By comparison with the alternative of further increasing spending, such a strategy would raise national saving. Staff stressed that this would not imply a change in the current three-year DELs, only that no significant new (i.e., previously unannounced) budget initiatives be introduced that would whittle down each year's fiscal overperformance. ${ }^{17}$

\section{The authorities agreed that their budget projections were cautious, and}

deliberately so, but were skeptical of some of the staffs arguments. Their budget plans were very explicit in moving to borrowing over the medium-term as allowed for by the golden rule and the debt sustainability rule. ${ }^{18}$ Even so, the authorities' budget projections still allowed for a cyclically-adjusted surplus on the current balance so that the public sector would not, in

${ }^{17}$ Staff projections-which assumed no new fiscal measures-showed an overall balance over the medium-term. The difference over the PBR projections reflected several factors: (i) the authorities' fiscal forecast was based on a potential output growth assumption of $2 \frac{1 / 4}{4}$ percent per annum (rather than their central forecast of $2 \frac{1}{2}$ percent) while the staff's was based on a higher estimate of potential output growth of $23 / 4$ percent which partly takes New Economy effects into account (see Box 1); (ii) already realized savings in AME (such as lower interest payments, unemployment, and welfare) that were unlikely to be reversed were incorporated into the staff's projections, but not into the authorities' projections; and (iii) staff made less pessimistic assumptions regarding the future revenue elasticity of VAT. On the other hand, staff projections assumed that fuel tax rates would be reduced as proposed in the PBR which lowers revenues by about 0.2 percent of GDP annually compared with the PBR projection.

${ }^{18}$ Although with the sharp fall in net public debt there was, in principle, sizeable-and possibly excessive-room to expand public investment, they noted that, in practice, it was not possible to increase public investment too rapidly, particularly given the administrative safeguards to ensure accountability and the cost-effectiveness of public spending. 
the central case, necessarily be financing all of its investment needs through borrowing. The authorities questioned the extent to which domestic savings was a constraint: since private investment could be financed from abroad, the more relevant constraint was the availability of projects with adequate rates of return. However, while they clearly expressed their commitment to deliver the envisaged increases in public spending, they did not exclude the possibility that, if revenues turned out stronger than assumed in the medium-term fiscal plans, they could have a smaller deficit than currently envisaged.

\section{Structural Policies}

33. Structural policies are a key part of the Government's agenda to achieve high levels of employment and to strengthen the United Kingdom's productivity performance. Following labor market reforms which began a decade and a half ago, the achievements with regard to employment growth and reduction in unemployment have been impressive, although there still remain some areas for improvement. The record on productivity growth, on the other hand, has been disappointing. Increasing the economy's total factor productivity (TFP) growth, particularly in sectors outside the New Economy, will be key for boosting productivity. Although the determinants of TFP are not well understood, current wisdom suggests that competition, entrepreneurship, innovation, and research and development (R\&D) as well as education and skill levels are factors. Sustaining the current high levels of investment will also be important, particularly by fostering higher private saving - a motivating factor behind the Government's pension reforms - and by ensuring a stable and well-supervised financial system that is able to intermediate savings and diversify risk efficiently.

\section{Analysis of the United Kingdom's New Economy suggests sizeable ICT} investment and productivity gains in the ICT sector, but very low productivity growth in the rest of the economy. When price deflators that allow fully for quality improvements are used to revalue nominal investment, the United Kingdom appears to have been investing in ICT at rates comparable to those of the United States and for almost as long. ${ }^{19}$ About onequarter of the growth in labor productivity in 1997-99 occurred through the contribution of ICT to capital deepening - that is, through an increase in the ICT capital stock per worker (Box 4). Moreover, TFP attributable to the computer-producing sector appears to have been growing at about the same rate as that in the United States. ${ }^{20}$ These findings suggest that TFP growth in the non-ICT sector has been even weaker in the late 1990s than previously thought, which increases the productivity puzzle and underscores the importance of raising TFP growth outside the ICT sector.

\footnotetext{
${ }^{19}$ These issues are discussed in greater detail in the Selected Issues paper "The "New Economy' in the United Kingdom."

${ }^{20}$ Excluding the large gains in the U.S. semiconductor industry since the United Kingdom does not have much semiconductor production.
} 
35. In this context, the authorities' policies to promote innovation and research and development (R\&D), strengthen competition, and encourage entrepreneurship are important components of the strategy to raise productivity growth. To strengthen the competitive environment, the government has modernized the legal and institutional framework and has placed a high priority on the rapid implementation of the Competition Act, passed in 1998, and on bolstering the powers and resources of the Office of Fair Trading. To promote innovation and $R \& D$, government initiatives are aimed at removing market failures and narrowing the difference between social and private returns, for instance through investment allowances and generous R\&D tax credits for small- and medium-sized enterprises (SMEs). Also, the Government has introduced various tax advantaged share ownership and share option schemes that are aimed at facilitating the creation of startup firms and encouraging entrepreneurship. Some of these measures, however, appear tilted towards, and sometimes confined to, SMEs. Staff suggested that a more effective approach would be to introduce measures aimed at promoting basic investment and R\&D in all firms-with generosity of the fiscal incentives adjusted accordingly. The authorities were open to such ideas, although they noted that some firms suffer from specific market failures and therefore deserve special treatment.

36. The United Kingdom's deficiencies with regard to education and skill levels have been identified as a factor behind its weak productivity performance. ${ }^{21}$ Cross-country studies have highlighted weaknesses in basic literacy and numeracy skills amongst the general population. In addition, intermediate and vocational skill levels of the workforce have lagged with respect to countries like Germany while the proportion of individuals with university training - particularly in key areas such as managerial skills - is lower than in the United States. The authorities are increasing spending on education partly through increases in meritbased pay for teachers and additional funding to raise the numbers of students entering higher education as well as setting higher standards throughout the school system. Staff noted the need for a strategy aimed at addressing the specific weaknesses of the U.K. education system and the skill deficiencies of its labor force, particularly given the increasing importance of the knowledge-based New Economy.

37. The Government's objective of achieving high levels of employment is being met, but employment rates among low-skilled men remain an area of concern. Labor market reforms since 1980s appear to have contributed to impressive increases in employment, with female participation rates rising markedly and concomitant declines in the unemployment rate, especially among the long-term jobless. However, activity rates for younger men with lower skill levels have been declining, perhaps partly due to increased participation in education and training. The authorities have introduced various New Deal initiatives aimed at reducing unemployment and joblessness among specific demographic groups such as youth, lone

${ }^{21}$ Education deficiencies in the United Kingdom and their impact on productivity and earnings have been documented by Crafts and O'Mahony (2000), and in other publications by the National Institute of Economic and Social Research and the Institute for Fiscal Studies. 
parents, and workers above 25 years of age. ${ }^{22}$ While initial results appear positive, obtaining lasting reductions in unemployment among remaining participants will be challenging. Staff noted in this regard that unemployment benefits in general should be tapered in a manner that reduced disincentives to work, including to prevent repeated enrollment in New Deal programs while remaining unemployed for long periods. In addition, current efforts to link unemployment benefits and welfare payments to job search could be strengthened by extending coverage to housing and disability benefits. While the National Minimum Wage introduced in 1999 appears to have had little negative effect on employment and inflation thus far, the mission observed that significant increases in the minimum wage could become a constraint on employment for low-skill workers in less propitious economic circumstances. Likewise, unifying the adult and youth minimum wages would impede prospects of integrating younger less-skilled workers into the workforce.

38. The pension system is a potentially important means of fostering private savings and channeling funds for investment; reform of the system has progressed, but staff urged caution with regard to further discretionary increases in state pension benefits. Unlike most other European countries, the United Kingdom does not have a substantive longrun pension problem, but the Government has introduced pension reforms partly to encourage long-term saving among certain lower income groups. Notably the planned introduction of market-based stakeholder pensions in April 2001, should catalyze the private provision of affordable pensions to about a quarter of the employed population which has been excluded from existing schemes - raising their savings without burdening the public finances with future liabilities. ${ }^{23}$ Aside from the reforms, the November PBR expanded means-tested allowances for low-income pensioners and introduced a pension credit that tapers off gradually the benefit withdrawal rate in order to palliate the associated disincentives to save. Although these measures were focused on reducing poverty, they will, nevertheless, eventually place about half of pensioner households on some form of state benefits linked to average earnings. The PBR also introduced a discretionary increase in the universal pension-which is, in principle, indexed to prices - at a sizeable budgetary cost. ${ }^{24}$

\section{Financial Sector Policies}

39. A stable, well-supervised, competitive financial system is an important part of the strategy to foster higher levels of productivity growth. Against the backdrop of expanding credit markets, the banking sector has continued to show strong profitability and capitalization, but the authorities were vigilant regarding possible vulnerabilities in

\footnotetext{
${ }^{22}$ The New Deal and other labor market reforms are discussed in SM/00/28 and SM/00/33.

${ }^{23}$ The U.K's pension reforms are discussed in Annex I of SM/00/28.

${ }^{24}$ The cost of the discretionary increases in the basic pension and in the minimum income guarantee included in the November $2000 \mathrm{PBR}$ is estimated at about 0.2 percent of GDP per year starting 2001/02.
} 
the current riskier environment. Capitalization of U.K. banks remains at comfortable levels reflecting sizeable returns on equity since the mid-1990s and high retail profit margins which have been buoyed by cost controls and the strong growth of high-yield lending (Box 5 and Table 5). Nevertheless, there are increasing risks on both the domestic and external fronts. In terms of domestic factors, the growth of high-yield lending also reflects riskier, unsecured (e g. credit card) lending which has increased at an average annual rate of about 16 percent over the last five years, although these claims still remain a small proportion ( $81 / 2$ percent) of the banks' total lending. Corporate and mortgage lending has also expanded rapidly and the levels of indebtedness of the household and corporate sectors are now close to previous peaks on several measures. While agreeing with the need to remain alert to the risks arising from growing indebtedness, the authorities noted that banks' exposure to vilnerable companies had declined over the past three years and that the underlying soundness of the property marketto which much lending was related-was significantly greater than at the previous cyclical peak. The authorities shared the mission's concern about the growing concentration of banks' exposures to the telecommunications sector, which has recently been estimated by the Financial Services Authority (FSA) at about 5 percent of total assets and 40 percent of total capital of the commercial banking sector. The authorities indicated, however, that the exposures were mainly to investment-grade borrowers rather than to the smaller, riskier companies and that the loans were mostly short-term. On the external front, the international exposures of U.K. banks grew by 10 percent in the year to June 2000 . However, exposures to emerging markets remained small compared to other industrialized countries (about 13 percent of the total). Overall, while acknowledging the increased risks, the authorities viewed U.K. banks' capitalization as adequate and their risk management techniques as appropriate. The staff agreed but noted that, while each of the above risks were individually quite manageable, there was a need to take account of their possible correlation.

40. The financial supervisory structure in the United Kingdom is coalescing well as the FSA continues progress toward a full integration of nine previously existing regulatory bodies, with competition-enhancing policies taking an increasingly relevant role. The Financial Services and Markets Act, which provides the formal framework for the single regulator, was passed in June 2000 and the forthcoming publication of an integrated handbook of rules spanning across different sectors will be a major milestone in the process. The adoption of the secondary legislation necessary to implement the Financial Services and Markets Act is scheduled for mid-2001. The Lnited Kingdom has agreed to undertake a FSAP, possibly in late 2001, after the authorities and financial institutions have acquired some experience with the new regulations. Given the continuing consolidation of the U.K. banking sector, the government commissioned an independent report (the Cruickshank report) to investigate competition issues. Its conclusions, presented in May, showed evidence of significant informational problems and collusive practices affecting retail customers and smalland medium-sized enterprises. The FSA has agreed to look into the possibilities for implementing some of the recommendations of the report, particularly those aiming to enhance competition by mandating better levels of disclosure and transparency and by setting up a framework for the effective comparison of prices of financial services 


\section{Other Issues}

41. The authorities' policy regarding EMU entry has remained unchanged, including the intention to assess the decision early in the next Parliament on the basis of the announced economic tests. ${ }^{25}$ The authorities are making preparations so that, should a decision to join early in the next Parliament be made, it would be feasible to implement it. As noted by the staff last year, the current state of economic analysis and empirical evidence does not provide an overriding case in favor or against U.K. membership at this time; however, the five criteria for joining adopted by the authorities appear broadly consistent with the economic considerations that would be important for the decision to enter a monetary unionparticularly those that aim at a sustained convergence between the cyclical positions of the United Kingdom and the euro-area economies. ${ }^{26}$ Apart from the exchange rate issue, the staff noted that cyclical synchronization had strengthened in 1999-2000.

42. On trade policy, the authorities expressed their support for the European Commission's proposal to grant duty- and quota-free access for exports from least developed countries. Staff also encouraged them to make more ambitious commitments on services at the WTO round.

43. The authorities expressed their commitment to bolster official development assistance (ODA) by raising the budgetary allocations to reach 0.33 percent of GNP by $\mathbf{2 0 0 3 / 0 4}$, including the announced one hundred percent bilateral debt write off in the context of HIPC. In the July 2000 Spending Review, the budget for the Department for International Development was set to increase by an annual average of 6.2 percent in real terms over 2001-2003.

44. On statistical issues, while the overall quality and availability of data are high (see Appendix III) in the United Kingdom, the mission stressed that it will be important to move quickly with efforts to capture the New Economy in the data. The authorities were aware of this need and noted that they were in the process of developing separate ICT data categories (subject to additional funding) and were investigating better qualityadjustments to the associated price deflators

\section{STAFF APPRAISAL}

45. The U.K. economy continues to perform well. The eight years since the 1990-92 recession marks the longest period of sustained output and employment growth and low and stable inflation in more than 30 years. Nonetheless, the expansion remains vigorous with little

${ }^{25}$ The authorities' policy towards EMU membership was stated by the Chancellor in October 1997.

${ }^{26}$ The appropriateness of these tests and the arguments for and against EMU entry are analyzed in SM/OO/28 and the associated Selected Issues Paper SM/00/33. 
sign of imbalances. Output is continuing to expand at a brisk pace and, despite high levels of resource utilization, inflation remains subdued, aided in part by benign wage developments and strong sterling.

46. Strengthened macroeconomic and structural policies, underpinned by improved monetary and fiscal policy frameworks, have contributed importantly to the United Kingdom's achievements. The tightening of fiscal policy in the late 1990s and a fiscal policy framework that has improved transparency and provided a medium-term orientation to policy have helped increase private sector confidence. The credibility of monetary policy has been enhanced with the adoption of a framework that provided for the operational independence of the Bank of England, a clear inflation target, and increased transparency of monetary policy decisions. A decade and a half of structural reform and deregulation have also contributed to a strong labor market and more competitive product and capital markets.

\section{A key challenge now is to sustain the ongoing economic expansion through} proper demand management. First and foremost, this will require great prudence on fiscal policy in 2001/02. The fiscal position remains sound. However, while the current fiscal expansion most likely can be accommodated without significant overheating, it will contribute to a policy mix that will tend to keep the exchange rate elevated. It would be prudent therefore to avoid burdening monetary policy even more by introducing significant new spending commitments or substantial tax cuts in the March 2001 budget. This would also mark a welcome break from the past tendency towards expansionary election-year budgets.

\section{The monetary policy framework appears to be working well and staff concurs} with the MPC's decision to leave the policy rate unchanged thus far; but the authorities will need to stand ready to cut rates if downside risks, particularly from a deteriorating external outlook, materialize. Although we agree that there was no pressing need to cut rates in December and January, the ongoing global slowdown seems likely to lower inflation risks further down the road. In addition, the recent sharp cuts in U.S. interest rates raise the possibility of a strengthening of sterling if U.K. rates are not lowered. Thus, if wage pressures continue to be moderate and signs emerge of weakening domestic activity, the authorities should not hesitate to cut the policy rate

49. From a medium-term standpoint, the key priority is to boost productivity growth. The authorities are fully aware of this need and have adopted various measures to that end. However, their approach could be strengthened further. In the fiscal area, the authorities' medium-term strategy is broadly appropriate, but there may be scope for the public sector to play a more ambitious role in promoting national saving and investment. Plans to boost public investment in infrastructure and human capital are justified in light of the United Kingdom's obvious weaknesses in these areas. However, if as is likely, revenues continue to overperform, it would be preferable to fund all public investment through higher public saving, as is now the case, rather than increasing expenditure further to achieve an overall deficit over the medium term.

50. Staff supports the focus of policies to encourage innovation and entrepreneurship, promote research and development, and to strengthen competition, 
particularly in view of the need both to foster the New Economy and to boost productivity growth in the rest of the economy. Reforms in these areas are rightly intended to aim at correcting identified market failures. Rapid implementation of the Competition Act and strengthening the powers and resources of the Office of Fair Trading are welcome in this regard. However, some measures - for instance, $R \& D$ tax credits, investment allowances, and reductions in capital gains taxes - may be too narrowly confined to SMEs.

51. A decade and a half of labor market reforms are yielding impressive results, but a strengthening of the education system and improvement of skill levels are clear priorities. The remarkable achievements with regard to the expansion of employment and the reduction in unemployment speak for themselves. However, education and skills gaps in the U.K. workforce in comparison with those of other major industrialized countries and employment rates for lower skilled men remain areas of concern. The New Deal programs appear to be working well on the whole, although there may be room for increasing the disincentives for participants to remain unemployed for long periods and for linking unemployment benefits and welfare payments (e.g. housing and disability benefits) more closely with job search. The National Minimum Wage (NMW) has had little impact on employment and inflation, but significant increases in the NMW should await an evaluation in times of greater labor market slack, particularly with regard to the impact on low-skill workers. Maintaining the youth exemption is similarly important from the perspective of integrating younger, lower-skilled entrants to the workforce

52. The progress with regard to pension reform is welcome, but some caution may be needed with regard to additional budget measures that could further increase public pension-related commitments. The experience under stakeholder pensions bears watching from the perspective of lessons that can be learned on private pension provision for lower income groups. The recent Pre-Budget measures have rightly focused on alleviating poverty among pensioners while safeguarding the incentives of current workers to save. However, there is need for caution in undertaking further public pension-related commitments, particularly those that are indexed to average earnings, given the possible implications for future public liabilities.

53. The banking system is profitable and well-capitalized, but the authorities will need to continue to be vigilant. Household and corporate gearing ratios are high and strong competition is eroding margins. Moreover, the concentration of banks' exposures to the telecommunications sector bears close monitoring as the FSA is already doing. It will be important to take account of the possible increased correlation in these risks, particularly if global financial market weaknesses feed into domestic market confidence. The implementation of some of the recommendations of the Cruickshank Report to mandate better disclosure by banks should help improve competition and enhance consumer protection. The United Kingdom's intention to participate in a FSA, possibly in late 2001, is welcome.

54. The decision to enter EMU remains a key medium-term issue with potentially far-reaching consequences for the United Kingdom. The five "tests" or criteria set out by the authorities reflect well the economic considerations that are important to the decision to enter a monetary union. Sustained convergence, in particular, is a key consideration and 
recent experience suggests that cyclical synchronization between the United Kingdom and the euro area is increasing.

55. The authorities' commitment to raise ofricial development assistance to 0.33 percent of GNP by $2003 / 04$ is welcome, including the full bilateral debt write-off in the context of HIPC. We encourage them to accelerate progress toward the U.N. target for overseas aid spending of 0.7 percent of GNP.

56. The United Kingdom publishes data on a sufficiently timely and comprehensive basis to permit effective surveillance. It would be useful to move forward quickly with efforts to ensure that the New Econorny is being captured accurately in the data, including developing separate ICT data categories and better quality-adjustments to the associated price deflators

57. It is proposed that the next Article IV consultation with the United Kingdom will be held on the standard 12-month cycle. 


\section{Box 1: Potential Output and the NAIRU}

This box explains the basis for the staff's estimates of NAIRU and potential output growth which partly take into account the New Econony - a factor that has been identified as raising the supply potential of the economy. The degree to which the supply potential is affected is highly debated and formal estimates vary. The staff's forecast of potential output for the United Kingdom takes the New Economy into account by isolating and revaluing the real capital stock associated with information and communications technologies (ICT).1/ With the new capital stock, a production function methodology is used to calculate potential output as:

$$
Y=a L^{\alpha}\left(K_{I C T}+K_{\alpha}\right)^{\left(1 \cdot \alpha \alpha^{\prime}\right.},
$$

where $Y$ represents the level of potential output, $a$ represents the level of total factor productivity (TFP), and $\alpha$ represents the share of labor income in total income attributable to the factors of production. In this formulation $\mathrm{K}_{\mathrm{ICT}}$ represents the real capital stock of ICT where the price deflators used to obtain the real capital stock from the nominal series for computers and office equipment, telecommunications equipment, and software consist of the most closely matching U.S. investment price deflators adjusted for the pound/dollar exchange rate. The remaining real capital stock, $\mathrm{K}_{\mathrm{o}}$ is the residual obtained by subtracting the nominal ICT capital stock from the total nominal capital stock and applying the U.K. price deflator associated with the entire capital stock. Because the U.S. deflators show sharper declines in the prices of ICT investment goods than the U.K. ones, the resulting growth rate of the total capital stock is increased relative to one calculated by the U.K. national statistics by about 0.1 percent per annum in $1994 \mathrm{Q} 1$ to about 1.4 percent $1999 \mathrm{Q} 4$.

The amount of labor, $L$, available to the economy is calculated as potential employment (those aged 18 to 65 ) multiplied by one minus the NAIRU. The staff's estimate of the NAIRU is as an unobserved component in a system comprising an expectations augmented Phillips curve that controls for supply side effects and a version of Okun's Law. ${ }^{2}$ For the United Kingdom, the NAIRU is estimated to have declined in recent years to a level around 5.5 percent based on the labor force survey definition of unemployment. Though the degree of uncertainty around this estimate is large, an analysis of micro data corroborates the lack of apparent wage pressure despite strong growth in employment and output (see Box 2).

The 2001-2005 forecasts for potential GDP growth using the above formula are about 2.8 percent per annum up from an average of 2,5 percent in the 1995-2000 period. These forecasts assume the following.

Capital Stock Growth. The annual growth in the non-computer capital stock is forecast to be about $23 / 4$ percent in 2001 dropping to about $2 \frac{1 / 4}{4}$ by 2005 . These forecasted growth rates are based on a deceleration following a period of high investment growth-some 6.3 percent per annum between 1995 and 1999. With the rate of investment growth forecasted to flatten, the rate of capital accumulation is expected to drop below the 3 percent rate experienced in recent years. Forecasting the growth rate of ICT capital is difficult given the associated high and variable annual real investment growth rates (ranging from 8 percent to 32 percent since 1995). Even though in some recent years real ICT investment growth has been quite high, a more conservativc assumption of 17 percent per annum, along with slightly slower price declines, is used for the forecast of the real ICT capital stock in light of the recent lower profit and sales of ICT firms.

Potential Labor Supply Growth. Potential employment is expected to grow at 0.6 percent for the next 2 years followed by 0.5 percent, similar rates to those used by the U.K. Treasury. The NAIRU is assumed to remain at its current level of 5.5 percent.

Total Factor Productivity Growth. It is difficult to project the long-nun TFP growth rate in the face of potential New Economy gains, particularly since it is difficult to observe any pickup in TFP for the economy as a whole in recent years. A growth tate of 0.9 percent per annum, which represents a rate between the historical high and low TFP growth rates over the previous two cyctical periods, is used. No attempt is made to incorporate potential New Economy gains to TFP growth (neither economy-wide nor in the ICT sector), but the positive effect on potential GDP results from the larger share and faster growing ICT capital stock in the total capital stock.

\footnotetext{
'See Box 4 and "The New Economy in the United Kingdom" in the accompanying United Kingdom - Selected Issues volume.

${ }^{2}$ The methodology is described in detail in the Selected Issues paper SM/00/234, 10/13/00.
} 


\section{Box 2. What's So Special About This Cyclical Expansion? A New Perspective from Labor Market Data}

There are a number of striking features of the current U.K. cyclical expansion that began in 1992-93. One is that, even by the late 1990 s and through 2000 , wage growth was not rising despite strong employment growth and notwithstanding the low level of unemployment and a historically high employment rate. Further, labor productivity growth has, on average, been weak, even by the U.K. 's own historical standards. This box summarizes the findings of a Selected Issues paper that uses individual-level labor market data to examine these and other developments. 1 /

It is possible that composition effects could explain the apparent puzzle of moderate average wage growth at this advanced stage of the current expansion. For instance, it is typically the case that business cycle expansions are associated with relatively higher growth rates of employment for low-skill workers, who have relatively lower wages. However, the background paper, based on an analysis of individual-level data from the New Earnings Survey, shows that, in the case of the current expansion, such composition effects cannot account for the subdued overall wage (and productivity) growth. In fact, the employment share of high-skill workers has actually increased during this expansion. Industry and regional composition effects on wage dynamics also do not appear to be important.

The Selected Issues paper suggests a different interpretation of developments during this expansion — one that is based on permanent positive country-specific shocks to underlying productivity. Two obvious candidates for such "shocks" in the U.K. are the labor market reforms that were instituted in the 1980 s and reinforced in the 1990s and, more recently, changes in monetary and fiscal frameworks that have resulted in a more favorable and stable macroeconomic environment in the latter half of the 1990 s.

The paper argues that these shocks increased the optimal level of the capital stock and, since capital and skilled labor are complements, the demand for skilled labor. Indeed, the rising skill wage premium documented in the paper is consistent with the notion of a move towards a more capital-intensive production structure and of capital-skill complementarity. A further conjecture is that, in a period when the composition of the capital stock was changing significantly (see Box 4), there could have been a considerable lag before workers and firns were able to employ new technologies and new components of the capital stock effectively. Thus, the transition path to a new steady state was one with apparently lower growth rates of mcasured labor prodictivity and TFP. Whether a sustained pickup in productivity growth will validate this latter interpretation remains to be seen.

However, this picture is consistent with available macroeconomic evidence-including high rates of business fixed investment (concentrated in the information and communication technology sector) and employment growth since 1992 and low labor productivity growth for much of the expansion, followed by a pickup in productivity growth in recent quarters. This hypothesis is also consistent with the nature of adjustment of labor inputs during this expansion. The fact that employers have, on average, adjusted labor inputs entirely in terms of employment rather than hours (either total or overtime weekly hours) during this expansion suggests that they are responding to a (perceived) permanent rather than temporary shock.

The increase in labor demand would, of course, result in higher wage growth unless offset by an increase in labor supply. Interestingly, during the last decade, there have been significant increases in the rate of transitions from longterm unemployment to employment as well as in participation and employment rates for women. These and other favorable developments in the latter half of the 1990 s could well be an example of the importance of interactions of institutions and shocks for determining labor market outcomes (a point made in the recent literature). $2 /$ If this interpretation, which is consistent with available micro and macro evidence, is correct, then the U.K. might finally be reaping the benefits of its structural reforms in terms of low structural unemployment and a possible pickup in the growth rate of productivity relative to its anemic growth rates in the mid-1990s.

\footnotetext{
${ }^{1}$ See "What's So Special About This Cyclical Expansion in the United Kingdom? A New Perspective from Labor Market Data" in the accompanying United Kingdom-Selected Issues volume.

${ }^{2} \mathrm{Sec}$, for instance, $\mathrm{O}$. Blanchard and J. Wolfers (2000), "The Role of Shocks and Institutions in the Rise of European Unemployment: The Aggregate Evidence "The Economic Journal", Vol. 110, pp. C1-C33.
} 


\section{Box 3. Strong Sterling and U.K. Competitiveness}

Sterling appreciated by almost 60 percent in real effective terms from $1996: Q 1$ to $2000: Q 2$ (see Figure 2), with $2 / 3$ of this appreciation taking place in the first two years. This box summarizes the findings of a Selected Isstres paper that considers the effects of the appreciation on the cconomy, in particalar on the composition of production in the tradable sector and on investment prospects. $1 /$

Although disparities in cyclical positions with respect to the euro area may have played a role, the appreciation is at the heart of the rapid deterioration in the external sector. The trade deficit has doubled since 1997 and the current account has shifted from a 0.8 percent of GDP surplus in 1997 to an estimated deficit of 1.3 percent of GDP in 2000, despite the United Kingdom being a small net exporter of oil products. In terms of components, export volumes declined sharply after 1996 and did not recover until late 1999, losing some market share in world as well as euro-area exports. Imports grew strongly during this period, and import penetration has achieved record levels. As a result, the external sector has made a significantly negative contribution to GDP growth since 1996.

As the relative profitability of tradables declined, the trend shift in the structure of output towards nontradables became more pronounced in the late 1990s: manufacturing outpul grew by an accumulated 2.2 percent over 1995-1999, while overall GDP grew by over 11 percent and the services sector grew by over 15 percent over the same period-a sharper shift than experienced in France or Germany, for instance. By comparison, during 1985-1990, a period with no apparent sizable misalignment of the exchange rate, accumulated growth in the manufacturing sector was 18 percent, compared to 18 percent for overall GDP and 17 percent for the services sector.

The question that arises is how U.K. firms have reacted to the strong exchange rate. Several points are worth highlighting.

- Manufacturing firms, having accumulated substantial profits after the post-ERM devaluation, followed a pricing-to market strategy, lowering prices and squeezing margins in order to protect market shares. Indeed, export prices in sterling declined sharply following the appreciation of sterling, especially to the euro area.

- Unil labor costs in manufacturing grew at a brisk pace since 1995 , owing to wage increases higher than for the whole economy, combined with very low labor productivity growth. Unit labor costs in manufacturing increased by about 18 percent over 1995-98, compared to small decline in France and Germany over the same period. This sizable increase in U.K. unit labor costs in manufacturing compounded the effect of the appreciation of the nominal exchange rate. Firms appear to have reacted only in late 1998, when a sudden increase in labor productivity permitted some containment of costs.

- Recent research from the Confederation of British Industry (CBI) indicates that many firms have shifted the supply-chain sourcing overseas as a means to combat the rising cost base brought about by the strength of sterling, thus raising imports and further widening the external deficit. The side effect of this phenomenon is the threat that it poses to firms further down the supply chain in those sectors, especially in terms of investment plans and long-term profitability.

- CBI survey data on investment expectations in manufacturing show a clear negative correlation with the real exchange rate (the correlation coefficient over 1980-2000 is -0.6). Twelve-month ahead investment expectations in manufacturing declined sharply in 1997, shortly after the appreciation of sterling began, and have not recovered since.

- An analysis of exports by sector shows that New Economy, high-value added sectors have been less affected by the exchange rate appreciation, growing consistently at higher rate than total exports. Conversely, low value added, traditional sectors, such as crude materials, food, clothing, and material mamufactures, have shown a disappointing performance.

Thus, it seems that a persistently high level of the exchange rate can have long-lasting negative effects on the external sector and on the sectoral composition of output. In terms of competitiveness, the crucial question is whether the strategies adopted by U.K. firms could be sustained in the long run were the exchange rate appreciation to persist. Unless productivity improves on a sustained basis and wage differentiation allows for moderate growth or even reduction of manufacturing unit labor costs, further erosion of margins may lead to diminished investment expectations and erode the production base of the tradables sector in the long nun.

'See "Strong Sterling and the United Kingdom's External Competitiveness" in the accompanying Cnited KingdomSelected Issues volume. 


\section{Box 4. So Where Is The "New Economy" in the United Kingdom?"}

While the United States is considered the foremost example of the "New Economy," other countries are also seeking to emulate its experience of non-inflationary growth in output and accelerated labor productivity. A focal point for evidence of the New Economy has been the link between the production and use of information and communications technology (ICT) and an acceleration of labor productivity. ${ }^{2}$ Like the United States, the United Kingdom has experienced low inflation accompanied by strong economic performance in the last several years, but unlike the United States, it has yet to see the confirming evidence of the New Economy in the labor productivity statistics.

Staff undertook an exercise for the United Kingdom similar to that done for the United States by Sichel and Oliner (2000) identifying the links between ICT investment and labor productivity growth. To examine these links real ICT output and investment were revalued using associated U.S. deflators that show larger quality improvements which are particularly evident in ICT goods. ${ }^{3}$ ICT can affect either the capital deepening component of labor productivity (the part associated with the amount of capital each worker has to work with) or the total factor productivity (TFP) component (a residual value representing possibly technological or organizational improvements that are not accounted for by other inputs). In the late 1990s, these two components contributed equal amounts to labor productivity. Within the capital deepening component, however, about one-half can be associated with investment in ICT capital. As yet, however, there is no sign of a significant pickup in economy-wide TFP that might be expected through ICT network effects, suggesting the disembodied synergies and spillovers of the New Economy have not been realized-at least as of 1999. A decomposition of TFP into that associated with the computer sector (measuring its ability to produce more output with given inputs) and the rest of the economy shows TFP growth in the computer sector on par with that of the United States, though TFP growth in the rest of the economy is considerably slower.

Table 1. Contributions to Labor Productivity for the United Kingdom, 1987-1999

\section{Growth Rate of Labor Productivity: 1/ \\ Contribution from: $2 /$ \\ Capital Deepening ICT}

Office Equipment and Computers

Software

Communications Equipment

Other capital

Total Factor Productivity

ICT sector $3 /$

Rest of economy $3 /$

$\begin{array}{ccc}\begin{array}{c}1987-1990 \\ 0.04\end{array} & \begin{array}{c}1991-1996 \\ 2.50\end{array} & \begin{array}{c}1997-1999 \\ 1.33\end{array} \\ 0.17 & 0.87 & 1.19 \\ 0.09 & 0.22 & 0.56 \\ 0.09 & 0.16 & 0.47 \\ \text { n.a. } & 0.03 & 0.05 \\ \text { n.a. } & 0.03 & 0.04 \\ 0.09 & 0.66 & 0.63 \\ 0.05 & 1.80 & 1.14 \\ \text { n.a. } & 0.32 & 1.35 \\ \text { n.a. } & 1.91 & 0.10\end{array}$

1/ Average annual log difference for years shown multiplied by 100 . Real GDP without revalued ICT sector.

2/ Percentage points year. Estimates below are for real GDP with revalued ICT sector, and thus do not sum to top line.

3/ For years 1993-1996 only, in which whole-economy TFP was 2.23 percent per anmum, and years 19971998, in which TFP was 1.45 percent per annum.

\footnotetext{
${ }^{1}$ This box summarizes "The 'New Economy' in the United Kingdom" in the accompanying United Kingdom Selected Issues volume.

${ }^{2}$ Oliner, Stephen and Daniel Sichel, "The Resurgence of Growth in the Late 1990s: Is Information Technology the Story?" Journal of Economic Perspectives, Fall 2000, 14:4, pp. 3-22.

${ }^{3}$ Although the United Kingdom uses quality adjustment methods in their computer price deflators, hedonic methods used in the United States show more rapid price declines. To the extent that U.S. deflators better represent the quality improvements, the productivity gains from ICT and the extent of ICT investment in the United Kingdom is underestimated.
} 


\section{Box 5. Financial Sector Risks and Vulnerabilities}

The financial sector continued in 2000 the trend of strong profitability and capitalization. U.K. commercial banks have been posting returns on equity well above 20 percent since the mid-1990s. Retail profit margins have held up reflecting, in large part, good cost control and the high growth of higher-yield unsecured (credit card) lending: however, interest rate margins are being slowly eroded by strong competition, especially in the mortgage market. High profits have allowed comfortable capitalization levels, with a capital asset ratio above 12 percent in 2000 . Despite strong lending growth, loan quality does not seem to have deteriorated; non-performing loans-although typically a lagging indicator of loan quality-remain low, at about 2 percent of total loans (Table 5). Provisions as a ratio to total lending have declined slightly, partly reflecting a teduction in provisions held against claims on countries affected by the $1997-98$ crisis.

Domestic credit markets are booming. Bank and building society sterling lending to the private sector (M4 lending) accelerated to an annual growth rate of 12.3 percent in October, the highest growth rate since 1990 (see Table 5). Both the household and corporate sectors show high levels of indebtedness.

- M4 lending to the household sector rose at a brisk pace. Unsceured credit card lending, which constitutes some 2.7 percent of M4 lending, grew at an annual rate of 18.2 percent in October. Against a background of stable (although high) house prices, growth of lending secured against dwellings remained strong at 8.3 percent in the third quarter of 2000 . Some of this lending has been used to fund current consumption. According to the Bank of England, the portion of secured lending used to finance consumption (mortgage equity withdrawal) bas been positive since 1999, in part fueled by recent innovations in mortgage products. Income gearing (interest payments over income) is at moderate levels, about half the peak of the late 19805. However, if gearing is computed as interest payments plus compulsory capital repayments, then the level is close to the previous cyclical peak.

- The growth of M4 lending to private non-financial corporations (PNFC) accelerated to 16.9 percent in the third quarter of 2000 , and the stock has reached levels comparable to the late $1980 \mathrm{~s}$. However, loan quality seems to be better than in the late 1980s: according to the Bank of England, lending to vilnerable companies represents only 4 percent of total lending ${ }^{1 /}$ compared with about 10 percent in 1990 . Lending to construction and real estate has soared, posting growth rates above 20 percent in the third quarter of 2000 (see Table 5). The increase in borrowing by PNFCs has raised the ratio of net debt slock to after-tax profits to levels similar to those of the late $1980 \mathrm{~s}$. However, the market value of PNFCs relative to curren after-tax profits has almost doubled since then, and therefore capital gearing (the ratio of net debt to the market value of firms) is still significantly lower than at the previous cyclical peak. Since mid-1999, PNFC's capital issuance and foreign currency borrowing has also gathered speed, owing in large part to larger expendifure on M\&As and 3G mobile phone licenses. The Bank of England estimates that about half of the external finance raiscd in the third quarter of 2000 went to the telecommunications sector.

- The concentration of exposures on the telecommunications sector merits some special attention. Total indebtedness of the telecommunications sector in 2000 is estimated by the Bank of England to reptesent about 16 percent of total debt of PNFCs (comparcd with only 6 percent in 1997). The FSA has estimated that it represents about 5 percent of total assets and 40 percent of total capital of the commercial banking sector. The potential risk of these exposures on the banking sector is difficult to assess at this stage. A large portion of this exposure may be short-lived, either in the form of short-term bridge financing pending a recovery of the corporate bond market or as bond holdings that may be passed on to nonbank investors later on. Moreover, about $2 / 3$ of the exposure is to investment grade-rated companies, mostly privatized former public sector monopolies or leading mobile license holders. However, the spreads charged for loans, and the recent downgrading of some of these companies, suggests some deterioration in credit quality in this sector. Furthermore, the enomous latent funding requirements to build up telecommunications networks could increase these exposures, thus heightening the risks.

External exposures have increased moderately, especially to the United States. About 40 percent of U.K. resident banks' on-balance sheet assets carry some cross-border risk. Extemal exposures of U.K.-owned banks increased by 10.5 percent in the first half of 2000, owing mainly to increased claims on industrialized countries. In particular, the exposures to the United States have increased steadily since 1999, and already represent about $1 / 5$ of total extemal exposures. Loan exposures of U.K, banks to emerging markets remain relatively small when compared with those of other industrialized countries. They increased by about 4 percent in the first half of 2000 , and represent about 13 percent of total overseas exposure. In terms of geographical composition, there has been a gradual shift away from East Asia and into Latin America and Middle East (claims on Argentina are the largest exposure to emerging markets, amounting to about 1.3 percent of total extemal exposures).

1/ Vulnerable companies are defined as companies which, in a particular year, fall into at least two of the following categories: highest quintile by capital gearing; lowest quintile by profitability; loweșt quintile by liquidily. 
Table 1 : Selected Eçonomic Indicators

\begin{tabular}{|c|c|c|c|c|c|c|}
\hline & 1996 & 1997 & 1998 & 1999 & $20001 /$ & $20011 /$ \\
\hline \multicolumn{7}{|l|}{ Rea] Econiomy (change in percent) } \\
\hline Real GDP & 2.6 & 3.5 & 2.6 & 2.3 & 3.0 & 2.7 \\
\hline Domestic demand & 3.0 & 3.8 & 4.6 & 3.8 & 3.9 & 3.4 \\
\hline CPI (excluding mortgage interest) & 3.0 & 2.8 & 2.7 & 2.3 & 2.1 & 2.5 \\
\hline Unemployment rate (in percent) $2 /$ & 8.1 & 7.0 & 6.3 & 6.0 & $5.33 /$ & $\ldots$ \\
\hline Gross national saving (percent of GDP) & 16.8 & 18.0 & 17.9 & 16.4 & 16.4 & 16.2 \\
\hline Cross domestic investrnent (percent of GDP) & 16.9 & 17.2 & 17.9 & $\$ 7.5$ & 17.8 & 18.1 \\
\hline \multicolumn{7}{|l|}{ Public Finance (in percent of fiscal year GDP) $4 /$} \\
\hline General government balance & -3.8 & -0.7 & 0.7 & 1.7 & $3.6 \mathrm{~s}$ & 0.5 \\
\hline Public sector balance & -3.6 & -0.7 & 0.6 & 1.7 & $3.5 \$$ & 0.4 \\
\hline Publie sector struetural balance & -3.0 & -0.3 & 0.6 & 1.7 & 1.1 & 0.4 \\
\hline General government gross debt & 52.2 & 49.2 & 46.5 & 43.6 & 40.2 & 37.4 \\
\hline Public sector net debt & 45.4 & 43.2 & 40.6 & 37.6 & 33.1 & 31.3 \\
\hline \multicolumn{7}{|l|}{ Money and Credit (end-year, percent change) } \\
\hline MO & 6.6 & 6.3 & 5.8 & 11.7 & 4.8 & $\ldots$ \\
\hline M4 & 9.5 & 5.7 & 8.3 & 4.1 & 8.0 & $\cdots$ \\
\hline Consumer Credit & 13.6 & 13.8 & 16.2 & 13.0 & 16.0 & $\cdots$ \\
\hline \multicolumn{7}{|l|}{ Interest rates (year average) } \\
\hline Three-month interbank rate & 6.0 & 69 & 7.4 & 5.3 & $5.9 \quad 6$ & $\ldots$ \\
\hline Ten-year Government bond yield & 7.8 & 7.0 & 5.5 & 5.4 & $4.96 r$ & $\ldots$ \\
\hline \multicolumn{7}{|l|}{ Balance of Payments } \\
\hline Trade balance (goods, in percent of GDP) & -1.7 & $\cdot 1.5$ & -2.4 & -2.9 & .3 .1 & -3.8 \\
\hline Current account (in percent of ODP) & -0.1 & 0.8 & 0,0 & -1.1 & -1.4 & -1.9 \\
\hline $\begin{array}{l}\text { Reserves (national valuation of gold, } \\
\text { end of period, in billions of SDRs) }\end{array}$ & 31.6 & 27.5 & 26.5 & 30.5 & 36.9 & $\ldots$ \\
\hline Reserves cover (months of imports of goods and services) & 1.1 & 0.9 & 0.8 & 0.9 & 1.1 & $\ldots$ \\
\hline \multicolumn{7}{|l|}{ Fund Position (As of December 31,2000 ) } \\
\hline Holdings of currency (in percent of quota) & & & & & 69.4 & \\
\hline Holdings of SDRs (in percent of alloculion) & & & & & $\$ 3.1$ & \\
\hline Quota (in millions of SDRs) & & & & & $10,738.5$ & \\
\hline \multicolumn{7}{|l|}{ Exchange Rate } \\
\hline Exchange rate regime & \multicolumn{3}{|c|}{ Floaling exchange rate } & & & \\
\hline Present rate (Jamuary 31, 2001) & \multicolumn{3}{|c|}{ US $\$ 1= \pm 0.685$} & & & \\
\hline Nominal effective rate $(1995=100)$ & 101.7 & 118.5 & 122.5 & 122.3 & 126.7 & $\ldots$ \\
\hline Reat effective rate $(1995=100) \pi$ & 102.4 & 124.6 & 137.3 & 142.4 & 154.4 & $\ldots$ \\
\hline
\end{tabular}

Source; National \$tatistics; HM Treasury; Bank of England; IMF, Intemational Financial Statistics; INS; and staff estimates.

U/ Staff projections, except where noted.

V/ Labor force survey basis.

3/ September - November 2000.

4/ Fiscal year beginning April 1.

5/ Includes 2.4 persentage points of GDP in 2000/01 corresponding to the auction proceds of spectrum licenses.

6/ Decenerer 2000.

7/ Based on relative normulized unit labor costs in manufacturing. 
Table 2. United Kingdom: Public Sector Budgetary Projectlons 1/ ( Percent of GDP and percent of potential GDP)

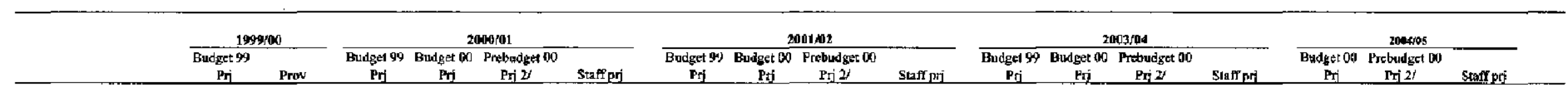

\section{Non-cyctically adjusted}

\begin{tabular}{|c|c|c|c|c|c|c|c|c|c|c|c|c|c|c|c|c|c|}
\hline Total revenue & 393 & 39.8 & 39.4 & 39.8 & $\$ 2.4$ & 42.6 & 39.5 & A0. 0 & 40.1 & 39.9 & 39.7 & 39.5 & 39.6 & 39.7 & 39.4 & 39.6 & 39.8 \\
\hline Curreat neverue $2 f$ & 39.2 & 39.7 & 39,4 & 39.7 & 39.9 & 40.1 & 39.5 & 39.9 & 40.0 & 39.8 & 39.7 & 39.4 & 39.5 & 39.6 & 39.3 & 39.5 & 39.8 \\
\hline Tax revenue & 36.6 & 37.3 & 36.7 & 37.1 & 37.3 & 37.5 & 37.0 & 37.4 & 37.5 & 37.3 & 37.1 & 37.0 & 37.1 & 37.3 & 369 & 37,1 & 37.4 \\
\hline Non-tax revenue & 2.6 & 2.4 & 2.7 & 2.6 & 2.6 & 2.6 & 2.5 & 2.5 & 25 & 2.5 & 2.6 & 2.4 & 2.4 & 2.4 & 2.4 & 2.4 & 2.3 \\
\hline Capital revenue $\$$ & 0.1 & o.t & 0.1 & 0.1 & $2.53 i$ & $2.53 \%$ & 0.1 & 0.1 & 0.1 & 0.1 & 0.1 & 0.1 & 0.1 & 0.1 & $0 . \mathrm{E}$ & 0.1 & 0.1 \\
\hline Toksl expenditure & 39.7 & 38.1 & 39.9 & 39.3 & 39.2 & 39.8 & 39.8 & 39.7 & 39.8 & 39.5 & 40.1 & 40.5 & 40.6 & 39.9 & 40.5 & 40.7 & 39.7 \\
\hline Current experdititure & 37.4 & 36.0 & 37.4 & 36.8 & 36.8 & 36.8 & 37.1 & 36.9 & 37.1 & 36.8 & 37.1 & 37.2 & 37.4 & 36.7 & 37.2 & 37.4 & 56.4 \\
\hline Privarary expenditure & 34.4 & 33.2 & $\ldots$ & 33.9 & 34.0 & 34,0 & $\ldots$ & 34.2 & 34.6 & 34.3 & $\ldots$ & 34.7 & 35.1 & 34.6 & 34.8 & 35.2 & 34.4 \\
\hline Imerest payments & 3.0 & 2.8 & $\ldots$ & 2.9 & 2.8 & $2 . x$ & $\ldots$ & 2.7 & 2.5 & 25 & $\ldots$ & 2,4 & 2.2 & 2.1 & 2.3 & 2.1 & 2.0 \\
\hline Capital expenditure 4 & 2.3 & 2.1 & 2.5 & 2.5 & 2.4 & 2.3 & 27 & 2.7 & 2.7 & 2.7 & 3.0 & 3.3 & 3.2 & 3.2 & 3.3 & 3.3 & 3.3 \\
\hline Curreut balance $5 /$ & 0.1 & 2.1 & 0.3 & 1.4 & 1.5 & 1.7 & 0.7 & 1.5 & 1.4 & 15 & 2.0 & 0.8 & 0.6 & 1.4 & 0.7 & 0.6 & 1.9 \\
\hline Overall balance & -0.5 & 1.7 & .0 .5 & 0.5 & 3.2 & 3.5 & -0.3 & 0.3 & 0.3 & 0.4 & -0.3 & -1.0 & -1.0 & -1.2 & 2.1 .1 & -1]$. & 0.1 \\
\hline \multicolumn{5}{|c|}{ Exeluding prowseds from speetrun licenses } & 0.8 & I.1 & & & & & & & & & & & \\
\hline Publec sector net debt 6 & 40,3 & 37.6 & 39.2 & 35.9 & 33.1 & 33.1 & 37.6 & 34.3 & 31.6 & 31.3 & 35.4 & 33,4 & 30.9 & 29,8 & 33.3 & 31.9 & 27.8 \\
\hline \multicolumn{18}{|l|}{ Cyclically adjusted 7} \\
\hline Total revenue & 39.5 & 39.8 & 39.8 & 39.8 & 39.9 & 40.2 & 39.9 & 40,0 & 40.0 & 39.9 & & & & 39.7 & & & 39.8 \\
\hline Current reverue & 39.5 & 39.7 & 39.8 & 39.7 & 39.8 & 40.1 & 39.8 & 39.9 & 40.0 & 39.8 & & & & 39.6 & & & 39.7 \\
\hline Tax rewethlue & 36.9 & 37.3 & 37.2 & 37.2 & 37.3 & 37.5 & 37.4 & 37.4 & 37.4 & 37.3 & & & & 37.2 & & & 37.4 \\
\hline Nom-tax revenue & 2.5 & 2.4 & 2.6 & 2.6 & 2.6 & 2.6 & 2.4 & 2.5 & 2.5 & 2.9 & & & & 2.4 & & & 2.3 \\
\hline Copital resenue & 0.1 & 0.1 & 0.1 & 0.1 & 0.1 & 0.1 & 0.1 & 0.1 & 0.1 & 0.1 & & & & 0.1 & & & 0.1 \\
\hline Total expenditure & 38.5 & 38.1 & 38.8 & 39.3 & 39.5 & 39.1 & 38.7 & 39.4 & 39.8 & 35.5 & & & & 40,0 & & & 39.8 \\
\hline Current expenditure & 36.2 & $\$ 6.0$ & 36.4 & 36.9 & 37.1 & 36.9 & 36.1 & 36.7 & 37.1 & 36.8 & & & & 36.8 & & & 36.5 \\
\hline Primay expenditure & 33.3 & 33.2 & $\ldots$ & 33.9 & 34.3 & 34.0 & $\ldots$ & 34,6 & 34.5 & 34.3 & & & & 34.6 & & & 34.5 \\
\hline Litereat payments & 2.9 & 2.8 & $\ldots$ & 3.0 & 2.9 & 2.8 & $\ldots$ & 2.7 & 2.5 & 2.5 & & & & 2,1 & & & 2.0 \\
\hline Capital expendituse & 2.3 & 2.1 & 2.4 & 2.5 & 2.4 & 2.3 & 2.6 & 2.7 & 2.7 & 2.7 & & & & 3.2 & & & 3.3 \\
\hline Current balanser 5 f & $\mathrm{t}, 6$ & 2.1 & 1.8 & 1.3 & 1.1 & 1.7 & 2.2 & 1.7 & 1.3 & 1.5 & & & & 1.4 & & & 1.8 \\
\hline Overall balance & 1.1 & 1.7 & 1.0 & 0.5 & 0.4 & 1.1 & 1.2 & 0.6 & 0.3 & 0.4 & & & & -0.3 & & & 0.0 \\
\hline Real wowth & 1.00 & 2.7 & 2.50 & 2.75 & 3.0 & 2.9 & 2.75 & 2.25 & 2.25 & 2.7 & 2.50 & 2.25 & 2.25 & $288 t$ & 2.25 & 2.25 & $2.8 \&$ \\
\hline Estimate of output gap & $\ldots$ & -0.0 & $\ldots$ & $\ldots$ & $\ldots$ & 0.1 & $\ldots$ & $\ldots$ & $\ldots$ & -0.0 & $\ldots$ & $\ldots$ & $\ldots$ & 0.1 & $\ldots$ & $\ldots$ & 4.1. \\
\hline
\end{tabular}

Sources: Nationat Statistics; HM Tressury; mand gialf estimater.

1/ Data for $2002 / 03$ hare been omitted for readability.

Data from the prebudget report 2000 have been adjusted to include the full spectum lieense revenue in 2000091 as capital revenas. This nevenue is exclud ef fropn the structural estimates.

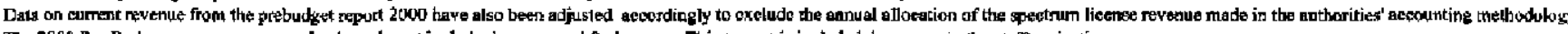

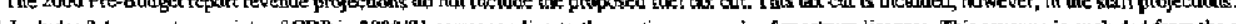

Thelutes 2.4 pprage

Capla expention

ris

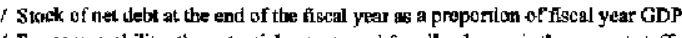

fortential output used for all columins is the current staff estimale

8/ Average growth sibce $2001 \% 03$ 
Table 3. United Kingiom: Contributions to Growth

(In percent)

\begin{tabular}{|c|c|c|c|c|c|c|c|c|c|c|}
\hline & \multicolumn{5}{|c|}{2000} & \multicolumn{5}{|c|}{2001} \\
\hline & $\begin{array}{l}\text { Q1 } \\
\text { Act. }\end{array}$ & $\begin{array}{l}\text { Q2 } \\
\text { Act. }\end{array}$ & $\begin{array}{l}\overline{Q 3} \\
\text { Act. }\end{array}$ & $\begin{array}{l}\text { Q4 } \\
\text { Prel. }\end{array}$ & $\begin{array}{l}\text { Total } \\
\text { Prj. }\end{array}$ & $\begin{array}{l}\text { Q1 } \\
\text { Prj. }\end{array}$ & $\begin{array}{l}\mathrm{Q} 2 \\
\mathrm{Prj} .\end{array}$ & $\begin{array}{l}\mathrm{Q3} \\
\mathrm{Prj} .\end{array}$ & $\begin{array}{l}\text { Q4 } \\
\text { Prj. }\end{array}$ & $\begin{array}{l}\text { Total } \\
\text { Prj. }\end{array}$ \\
\hline Real GDP growth & 0.4 & 1.0 & 0.7 & 0.3 & 3.0 & 0.7 & 0.7 & 0.7 & 0.6 & 2.7 \\
\hline $\begin{array}{l}\text { Domestic demand } \\
\text { of which }\end{array}$ & 0.3 & 1.5 & 1.0 & 0.7 & 4.0 & 0.8 & 0.9 & 0.9 & 0.7 & 3.6 \\
\hline Private consumption & 0.5 & 0.7 & 0.7 & 0.4 & 2.5 & 0.5 & 0.4 & 0.4 & 0.4 & 2.0 \\
\hline Private investment & -0.1 & -0.1 & 0.0 & 0.0 & 0.3 & 0.1 & 0.1 & 0.1 & 0.1 & 0.2 \\
\hline Public expenditure & -0.2 & 0.8 & 0.1 & 0.3 & 0.6 & 0.3 & 0.3 & 0.3 & 0.2 & 1.3 \\
\hline Stockbuilding & 0.1 & 0.2 & 0.2 & -0.1 & 0.6 & 0.0 & 0.0 & 0.0 & 0.0 & 0.0 \\
\hline $\begin{array}{l}\text { Foreign balance } \\
\text { of which }\end{array}$ & 0.2 & -0.5 & -0.3 & -0.4 & -0.9 & -0.1 & -0.2 & -0.1 & 0.0 & -0.9 \\
\hline Imports & 0.4 & 1.3 & 0.7 & 0.7 & 3.3 & 0.7 & 0.6 & 0.6 & 0.6 & 2.8 \\
\hline Exports & 0.6 & 0.8 & 0.4 & 0.3 & 2.4 & 0.5 & 0.5 & 0.5 & 0.6 & 1.9 \\
\hline
\end{tabular}

Source: Office for National Statistics (ONS); and staff projections. 
Table 4. United Kingdom: Medium-Term Scenario

(Percentage change, unless otherwise indicated)

\begin{tabular}{|c|c|c|c|c|c|c|c|}
\hline & 1998 & 1999 & 2000 & 2001 & 2002 & 2003 & 2004 \\
\hline Real domestic demand & 4.6 & 3.8 & 3.9 & 3.4 & 3.2 & 3.2 & 3.2 \\
\hline Private consumption & 4.0 & 4.4 & 3.8 & 2.9 & 2.7 & 2.8 & 2.7 \\
\hline Government consumption & 1.1 & 4.0 & 3.4 & 4.4 & 4.1 & 4.1 & 4.0 \\
\hline Fixed investment & 10.1 & 5.4 & 1.6 & 3.7 & 4,1 & 3.9 & 3.8 \\
\hline Residential & 3.3 & 0.9 & 2.4 & 1.4 & 3.4 & 3.7 & 3.6 \\
\hline Business & 10.9 & 7.6 & 1.7 & 1.4 & 2,4 & 2.6 & 2.7 \\
\hline Stocks $1 /$ & 0.1 & -0.7 & 0.6 & 0.0 & 0.0 & 0.0 & 0.0 \\
\hline External balance $1 /$ & -2.0 & -1.5 & -0.9 & -0.9 & -0.5 & -0.6 & -0.5 \\
\hline Exports & 2.6 & 4.0 & 7.5 & 5.9 & 6.5 & 6.6 & 6.5 \\
\hline Imports & 8.8 & 8.1 & 9.2 & 7.4 & 6.8 & 6.9 & 6.7 \\
\hline Current account $2 /$ & 0.0 & -1.1 & -1.4 & -1.9 & -2.3 & -2.7 & -2.9 \\
\hline Real GDP & 2.6 & 2.3 & 3.0 & 2.7 & 2.9 & 2.8 & 2.8 \\
\hline \multicolumn{8}{|l|}{ Inflation } \\
\hline $\begin{array}{l}\text { RPI X (excluding mortgage } \\
\text { interest) }\end{array}$ & 2.7 & 2.3 & 2.1 & 2.5 & 2.5 & 2.5 & 2.5 \\
\hline \multicolumn{8}{|l|}{ Employment and productivity } \\
\hline Employment & 1.1 & 1.3 & 1.1 & 0.6 & 0.5 & 0.5 & 0.5 \\
\hline Average unemployment rate & 6.3 & 6.0 & 5.5 & 5.5 & 5.5 & 5.5 & 5.5 \\
\hline Productivity $4 /$ & 1.4 & 1.4 & 2.5 & 2.4 & 2.4 & 2.3 & 2.3 \\
\hline
\end{tabular}

Sources: Office for National Statistics; and IMF staff projections.

1/ Contribution to the growth of GDP.

2/ In percent of GDP.

3/ In percent; Labor Force Survey basis.

4/ Whole economy. 
Table 5: United Kingdom: Indicators of External and Financial Volnerability (In percent of GDP, unless otherwise indicated)

\begin{tabular}{|c|c|c|c|c|c|c|}
\hline & 1996 & 1997 & 1998 & 1999 & $20001 /$ & \\
\hline \multicolumn{7}{|l|}{ Erternal indicators } \\
\hline Expors (znsual pereentage change, in U.S, dollats) & 7.7 & 9.2 & -0.5 & -0.6 & -6.4 & January-November 2 \\
\hline lomports (atmual pertentage change, in U.S. dollars) & 82 & 6.9 & 3.2 & 2,4 & -2.5 & January-November $2 /$ \\
\hline Terchs of trade (antrual percentage change) & 0.7 & 0.8 & 1.1 & 0.8 & 1.0 & Jamudy-Novemaber $2 /$ \\
\hline Current account balance & -0.1 & 0.8 & 0.0 & -1.1 & -1.4 & $\mathrm{Q} 1-\mathrm{Q} 321$ \\
\hline Capital and financial account balsnce & 03 & -1.8 & -0.5 & 1.3 & -0.4 & Q1-Q3 3f \\
\hline Of which: Foreign dirext investunent (net) & -0.8 & -2.0 & -4.0 & -8.5 & -11.8 & $Q 1-Q 32 /$ \\
\hline Fortolio investment (net) & -2.0 & -3.1 & -2.2 & 11.7 & 10.7 & QI-Q3 \\
\hline Other juwestment (act) & 3.0 & 3.2 & 5.6 & -2.0 & 2.2 & $\mathrm{QI}-\mathrm{Q} 32$ \\
\hline Net errors and omirsions & +0.4 & 2.7 & 0.5 & -2.4 & -1.0 & Q1-03 2 \\
\hline Official reserves (in billions of U.S. dollats, end of period) $3 /$ & 45.4 & 37.1 & 37.3 & 41.8 & 48.2 & December \\
\hline Central bank net foreign assets (in bithons of U.S. dollars) & -15 & -1.1 & 8.3 & -27 & -2.7 & November \\
\hline Foreign assets of banking institutions (in billions of U.S. dollars) & 1305.6 & 1704.9 & 1894.8 & 1834.7 & $2,063.2$ & Novernber \\
\hline Foreign Jiabilities of banking instirutions (in billions of U.S. dollars) & 1319.4 & 1722.1 & 1856.6 & 1826.5 & $2,043.1$ & Noweuber \\
\hline Exchange rate agajust U.S. dollar (beriod average) & 1.56 & 1.64 & 1.66 & 1.62 & 1.52 & \\
\hline \multicolumn{7}{|l|}{ Fioancial markets indicato rt } \\
\hline Public sector net debt & 44.0 & 43.1 & 40.7 & 38.6 & 32.9 & December 4/ \\
\hline 3-month T-bill yield & 6.2 & 7.3 & 5.8 & 5.6 & 5.6 & December $4 /$ \\
\hline 3-month T-bill yjeld (real) 5 ) & 3.7 & 4.7 & 3.0 & 3.8 & 2.6 & December 4 \\
\hline Change in stock market index (pereent, end of period) & 11.6 & 19.7 & 10.9 & 21.3 & .4 .6 & December $4 /$ \\
\hline Spread of 3-month T-bill vs. the U.S. (percentage points, end of period) & 1.0 & 2.0 & 1.4 & 0.2 & -0.3 & Dectmbes 4 \\
\hline \multicolumn{7}{|l|}{ Credit Indkatars 6/ } \\
\hline M4 knding & 9.7 & 11.6 & 7.8 & 8.8 & 11.4 & Decentoer \\
\hline \multicolumn{7}{|l|}{ M4 lending to individuals } \\
\hline Secured on dwellitigs & 5.7 & 5.8 & 5.7 & 8.0 & 6.0 & Deoenter \\
\hline Consumer credit & 14.9 & 16.1 & 18.2 & 15.2 & 16.0 & December \\
\hline Credit card & 18.2 & 19.3 & 21.8 & 17.7 & 19.4 & December \\
\hline M4 lending to private non financial corporations & 12.9 & 32 & 6.5 & 5.9 & 12.9 & Daxember \\
\hline Lending to construetion secter & .10 .9 & -3.8 & 10.9 & 7.1 & 29.3 & October \\
\hline Lending to real estate sector & 1,0 & -3.8 & 14.7 & 15.6 & 22.2 & Qctober \\
\hline Interest rale on personal loans $7 /$ & $\ldots$ & 18.1 & 18.0 & $\mathbf{3 4 9}$ & 15.7 & Dedember $4 /$ \\
\hline Interest rale orl fixeat rate martgages $7 /$ & $\ldots$ & 7.6 & 6.5 & 7.1 & 6.5 & December 4 \\
\hline Interest rate on time deposits 7 & $\ldots$ & 5.8 & 5.1 & 4,2 & 4,4 & December 4 I \\
\hline \multicolumn{7}{|l|}{ Financial sector rlsk Indicators \& } \\
\hline Total loans to assets (percent) & 85.1 & 83.9 & 82.4 & 82.4 & 82.0 & September \\
\hline Total loans to deposits (percent) & 94.0 & 94.5 & 93.1 & 93.5 & 92.2 & September \\
\hline Foreign exchaege loans (in USSbn) & 1241.2 & 1431.0 & 1535.7 & 1443.5 & 1587.3 & Sejtember \\
\hline Share of foreign exchange loatas in total lending (percent) & 40.3 & 42.2 & 41.1 & 39.2 & 40.9 & September \\
\hline Deposits in foreign exclange (in USfbr) & 1470.1 & 1651.1 & 1768.6 & 1698.7 & 1899.3 & Septamber \\
\hline Share of foreign deposits in total deposits (percent) & 51.1 & 55.7 & 55.5 & 55.5 & 56.7 & September \\
\hline Shat of fortign denominated liabilities in total liabilities (percent) & 49.0 & 50.9 & 50.7 & 49.8 & 52.0 & September \\
\hline Share of real estafe sector in private credit (percent) $9 /$ & 48.9 & 47.7 & 48.7 & 49.0 & 47.4 & September: \\
\hline Shars of regl extate sector in leans to non financial private corporations (percent) 7/ & 24.9 & 22.6 & 23.6 & 24.9 & 26.7 & September \\
\hline Share of non-performing loans in total toand $(\%) \mathrm{JO}$ & 2.3 & 2.4 & 2.2 & 1.9 & 2.2 & August \\
\hline Share of non-performing loans in total assets secter (\%) $10 \%$ & 1.4 & 1.7 & 2.1 & 2.4 & 2.] & August \\
\hline Capital asset ratio & 11.8 & 12.5 & 12.6 & 12.2 & 12.2 & Auguzst \\
\hline Profitability ratio. & $\mathbf{2 2 , 1}$ & 19.2 & 36.8 & 18.6 & 16.9 & Aurusi \\
\hline
\end{tabular}

Sourex: Data provided by the authorities; Office for National Statisties; Bank of England; and IMF, Iaicrnational Financial Statistics.

W For 2000 , end of period at the month indicated, untess otherwise noued.

2 Cumulative flow during the period indicated.

$3 /$ Lacluding gold, national valuation.

4/ Monthly avernge.

5/ Calculated as 3-month T-bill less actual 12-month RPI inflation in Des of retevant year.

6. Twelve-menth growth rates.

T) Weigthed averages for hariks and butidiag societies.

g End of period. Building sacieties and insurance companiess are excluded frott this sample. Deposits' inciudes cumency, depasits and moncy maricet instruments.

$9 /$ Excludes invęstments.

10/ The proxy figures for non-perferming loans represent the gross vatue of loans against which specific provisions lave been made. 
Figure 2, United Kingdom: Exchange Rates and Competitiveness Indicators
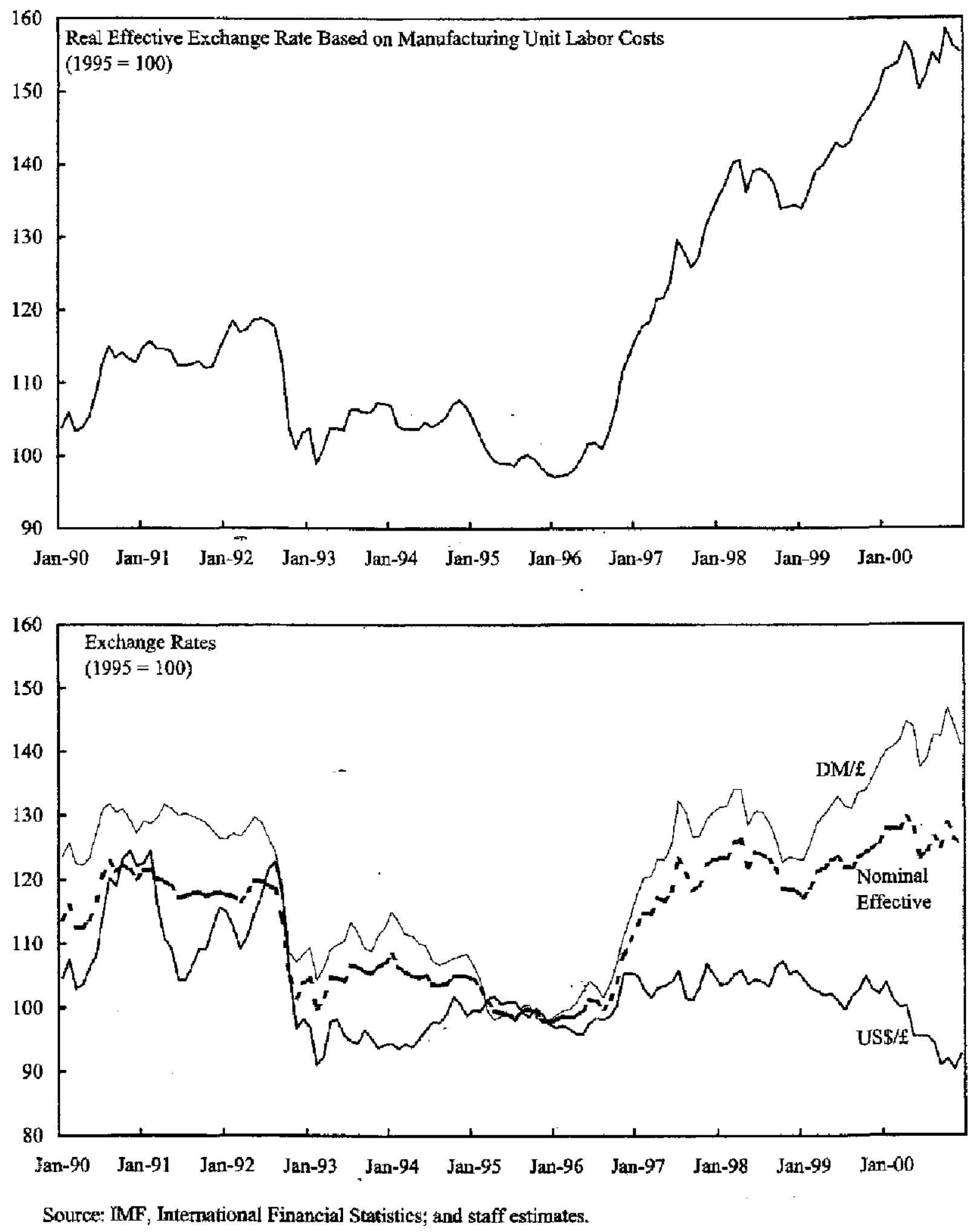
Figure 4. United Kingdom: Expenditure Contributions to Quarterly Growth of GDP

(In percent of GDP, unless otherwise noted)

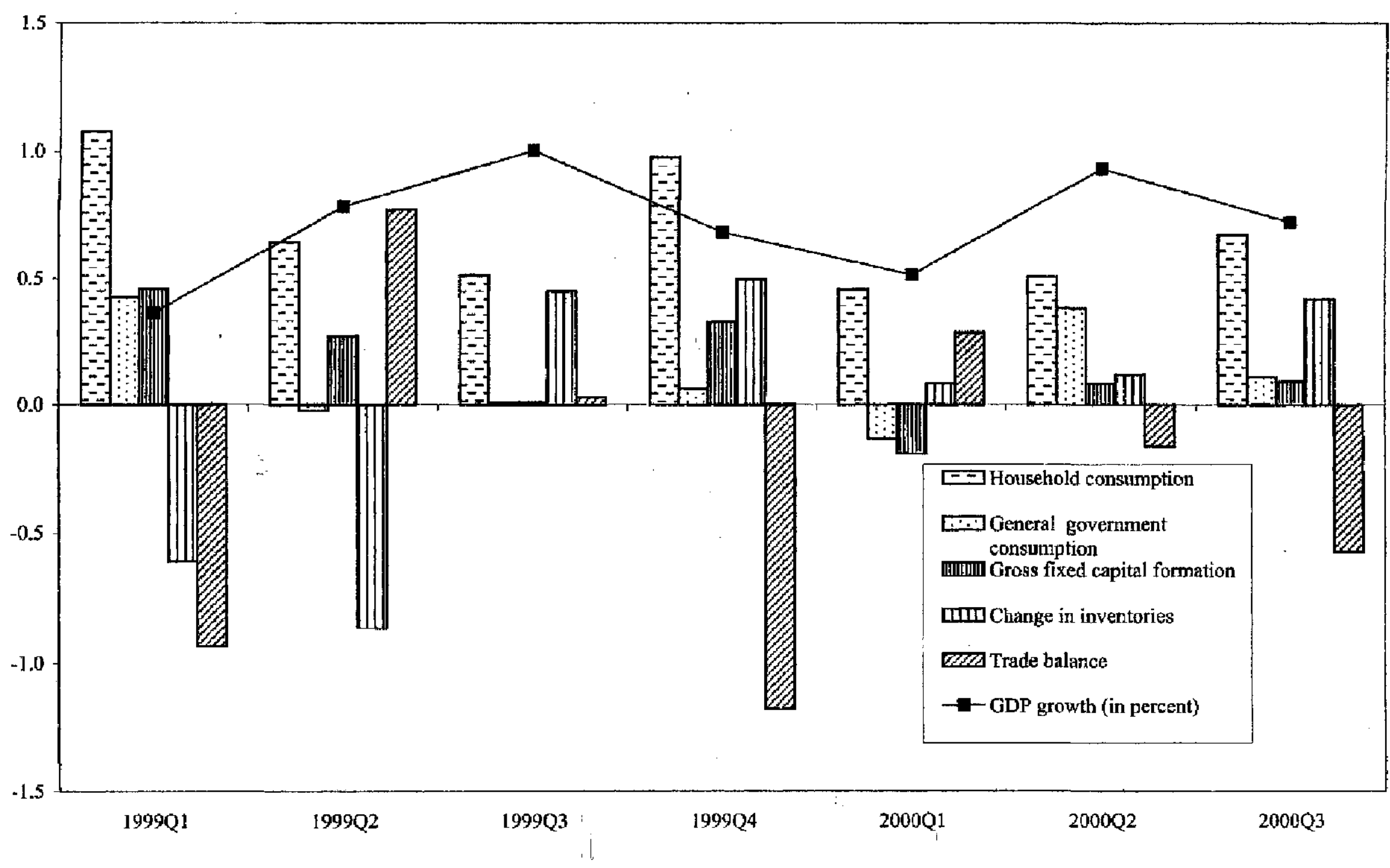

CInternational Monetary Fund. Not for Redistribution 
Figure 5. United Kingdom: Asset Prices and Confidence Indicators
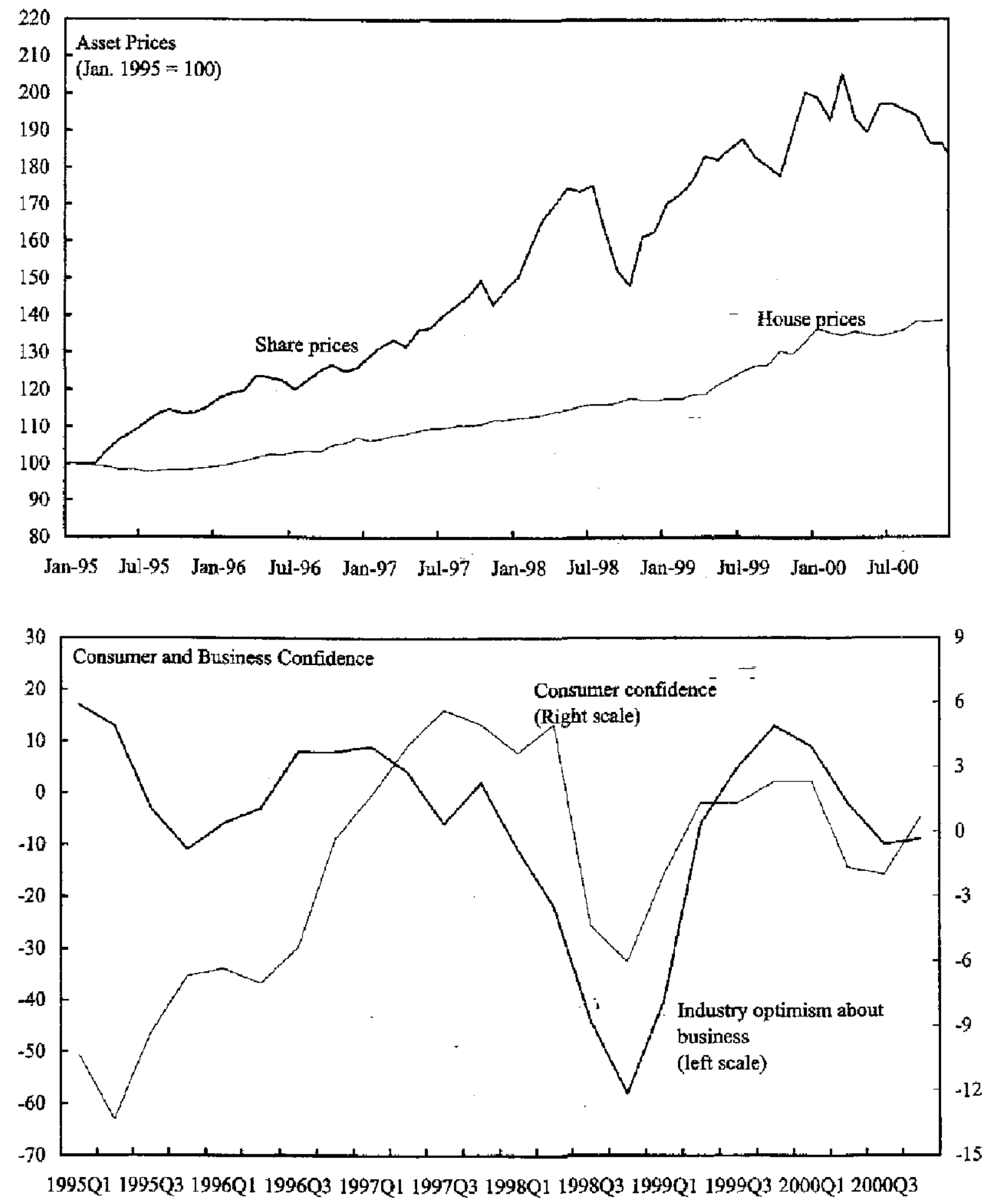

Source: Office for National Statistics (ONS); and Bloomberg. 
Figure 6. United Kingdom: Labor Market Indicators
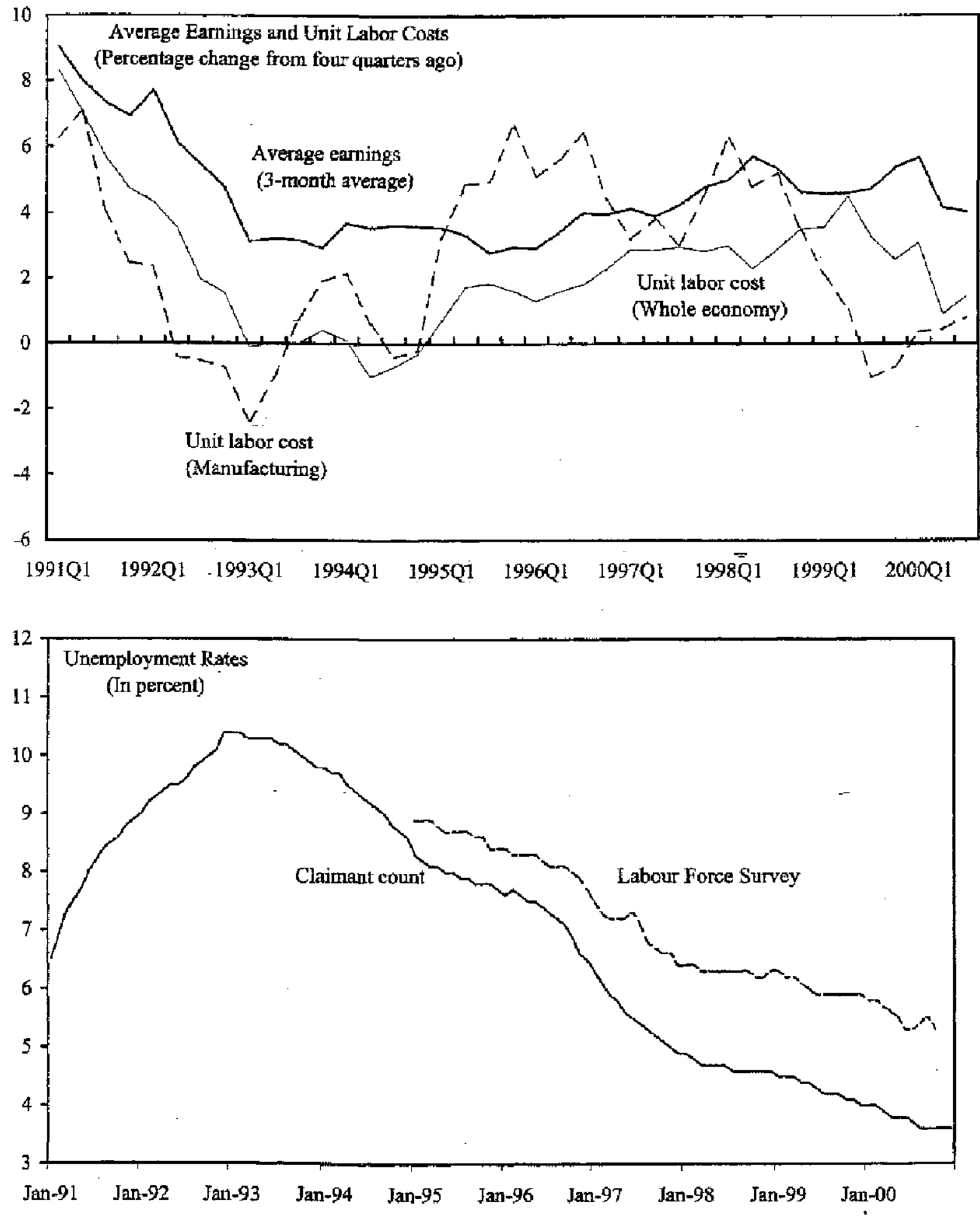

Source: Office for National Statistics (ONS). 
Figure 7. United Kingdom: Price Developments
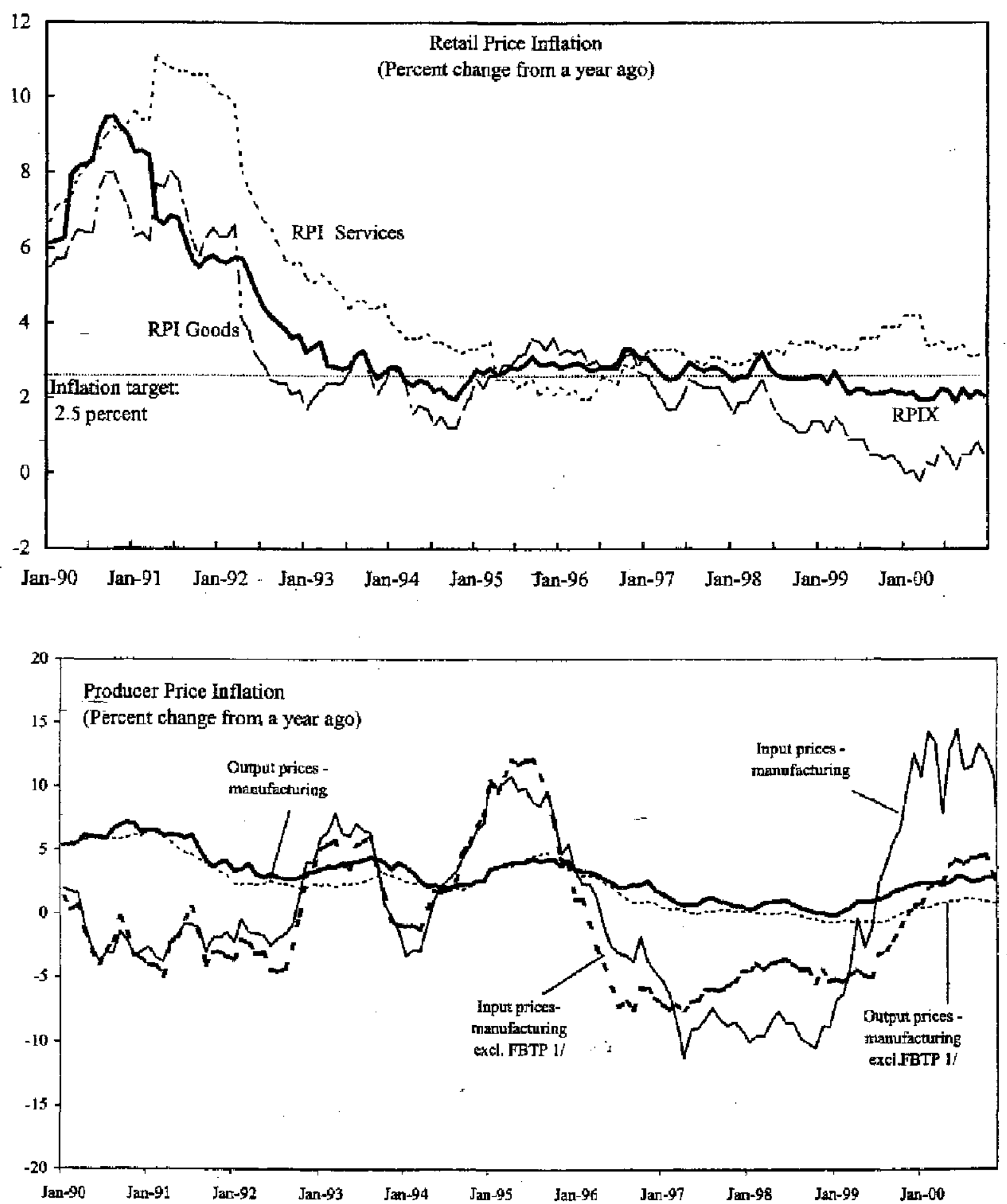

Source: Office for National Statistics (ONS).

1/ Manufacturing excluding food, beverages, tobacco and petroleum industries. 
Figure 9. United Kingdom: Interest Rates
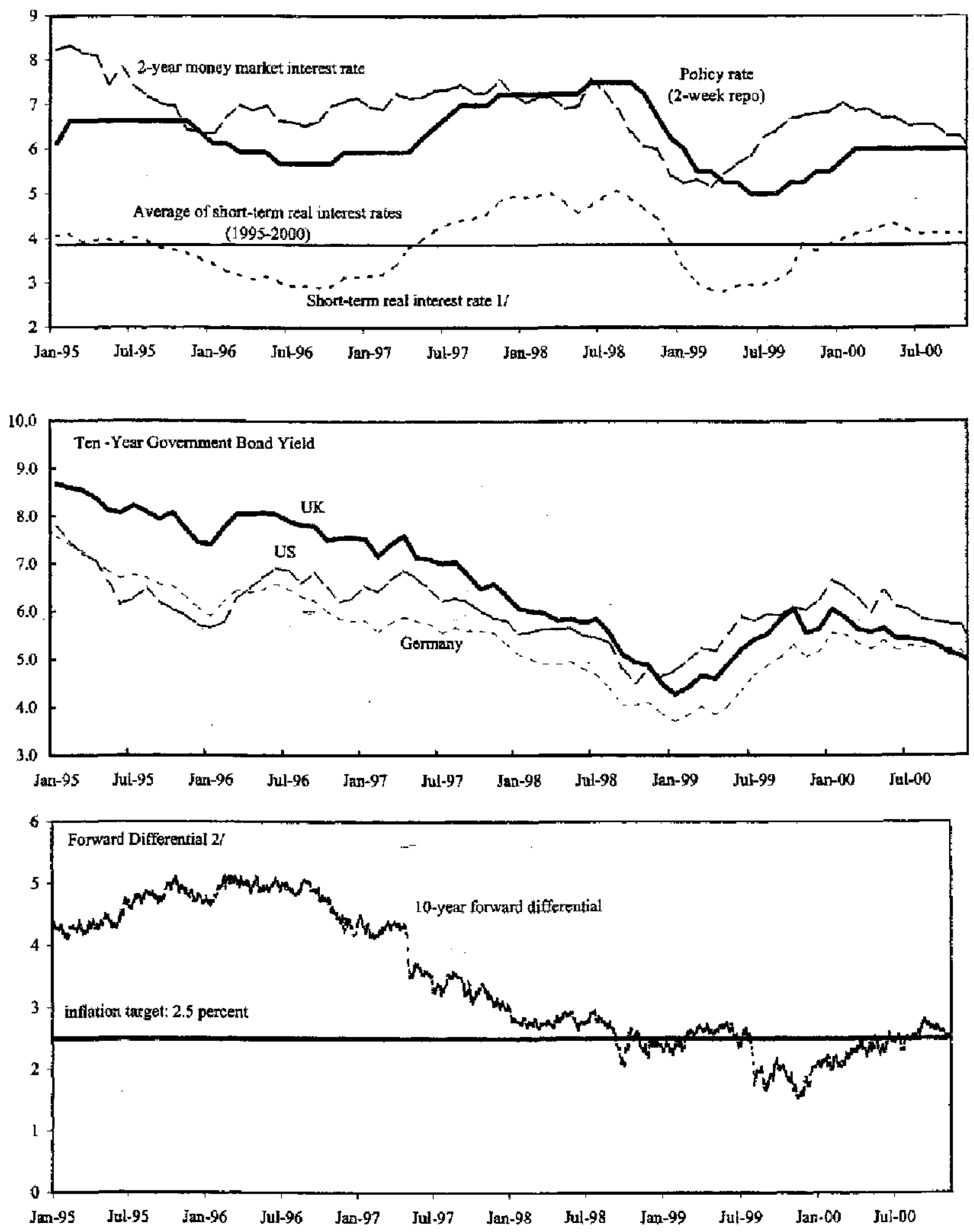

Source: Office for National Statistics (ONS); Bank of England; Bloomberg.

1/3-month nominal interest rate less headitine RPIX inflation.

2f Differential between a 10-year nominal and index-linked bond yields. 


\section{Simulating the Effects of the Fiscal Expansion}

According to the 2000 Pre-Budget Report, general government spending is set to rise in structural terms from 37.7 percent of GDP in 1999/00 to 40.1 percent of GDP in 2003/04, with a real rate of growth averaging about 4 percent per annum over 2000/01-2003/04. The increase in government spending is frontloaded because the targets, in ratios to GDP, remain essentially unchanged from those announced at the time of the Novernber 1999 Pre-Budget Report (which were broadly consistent with the medium-term profile announced in the 1999 budget), despite the lower spending outcome in 1999/00. This fiscal expansion is evenly distributed between government consumption in goods and services, transfers, and public investment

\begin{tabular}{|c|l|l|l|l|}
\hline \multicolumn{5}{|c|}{ Simulation scenario } \\
\hline & $2000-01$ & $2001-02$ & $2002-03$ & $2003-04$ \\
\hline & 1.2 & 1.7 & 1.8 & 1.9 \\
\hline Primary current expenditure & 1.2 & 0.8 & 0.8 & 0.9 \\
\hline Goods and services & 0.5 & 0.9 & 1.0 & 1.0 \\
\hline Transfers & 0.7 & 0.7 & 1.0 & 1.2 \\
\hline Capital expenditure & 0.4 & 2.4 & 2.8 & 3.1 \\
\hline Total primary expenditure & 1.6 & 0.5 & 0.5 & 0.5 \\
\hline Revenues & 0.5 & 0.5 & \\
\hline
\end{tabular}

Given that the policy choices currently at stake refer to 2001 onwards, this simulation takes "as given" the macroeconomic outturn in 2000 (where the expansionary effects of this fiscal expansion were probably combined with the lagged effects of past contractionary polices) and discusses the impact of these policy choices with a focus on its effects from 20010nwards'. The shock was simulated with OEF. It was modeled (Exercise I) by taking as the baseline a scenario where structural spending as a ratio to GDP is held constant at the 1999/00 level and introducing the 2000 PBR path as the "shock", as in the table above. Given the recent experience with revenue overperformance, an alternative scenario was also considered (Exercise II), whereby the increase in government expenditure is combined with a permanent increase in revenues of 0.5 percent of GDP over $2000-03$. The results appear in the table below.

\begin{tabular}{|l|rrr|rrr|}
\hline \multicolumn{3}{|c|}{$\begin{array}{c}\text { Estimated effects of increase in government expenditure and revenues } \\
\text { (deviation from baseline, in percent, unless otherwise stated) }\end{array}$} \\
\hline & \multicolumn{3}{|c}{ Exercise 1 } & \multicolumn{4}{c|}{ Exercise 2 } \\
& 2000 & 2001 & 2002 & 2000 & 2001 & 2002 \\
GDP & & & & & & \\
RPLX Inflation & 0.2 & 0.7 & 0.1 & 0.1 & 0.3 & -0.1 \\
Nominal interest rate 1/ & 0.0 & 0.2 & 0.5 & 0.0 & 0.0 & 0.2 \\
Real exchange rate & 0.3 & 0.8 & 0.5 & 0.1 & 0.4 & 0.1 \\
Current account/GDP 2/ & -0.1 & -0.4 & -0.5 & 0.2 & 0.3 & -0.5 \\
\hline
\end{tabular}

V/ In percentage points.

2/In percent of GDP.

According to the simulation (Exercise 1), GDP expands on impact, raising inflation expectations and leading the authorities to raise short-term rates to protect the inflation target. Because of this monetary policy reaction, the bulk of the cost is borne by the external sector, as the exchange rate appreciates and the current account

1 Thus, the results of the simulations for 2000 should be interpreted as the isolated effect of this expansionary policy, regardless of the stance of fiscal policy in previous years. 
deteriorates. Overall, the expansionary effect of the increase in government spending more than offsets the decline in net exports. However, this positive effect fades out as further increases in interest rates are needed to keep inflation under control and the subsequent appreciation of the exchange rate further deteriorates the current account. As a result, in 2002, GDP falls back broadly in line with baseline while inflation and interest rates remain above the baseline. If revenues are higher than expected (Exercise 2) the expansionary effect on activity is tamed, and the cost in terms of inflation and current acoount deterioration is smaller.

A caveat of this exercise is that the results depend heavily on the assumptions about the future path of potential output: a higher growth of potential output could accommodate the fiscal expansion without exerting undue pressure on inflation. The table below repeats Exercises 1 and 2 under the assumption that potential output growth is 0.5 percentage points higher than in the baseline scenario.

\begin{tabular}{|l|rrr|rrr|}
\hline \multicolumn{3}{|c|}{$\begin{array}{c}\text { Estimated effects of increase in government expenditure and revenues } \\
\text { with higher potential output growth } \\
\text { (deviation from baseline) }\end{array}$} \\
\hline & \multicolumn{3}{c}{ Exercise 1 } & \multicolumn{4}{c}{ Exercise 2 } \\
& 2000 & 2001 & 2002 & 2000 & 2001 & 2002 \\
& & & & & & \\
GDP & 0.2 & 0.8 & 0.8 & 0.1 & 0.4 & 0.6 \\
RPIX Inflation & 0.0 & 0.1 & 0.2 & 0.0 & -0.1 & -0.1 \\
Nominal interest rate & 0.2 & 0.4 & -0.4 & 0.1 & 0.0 & -0.7 \\
Real exchange rate & 0.3 & 0.2 & -1.4 & 0.2 & -0.1 & -1.2 \\
Current account/GDP & -0.1 & -0.4 & -0.3 & -0.1 & -0.2 & 0.0 \\
\hline
\end{tabular}

The results show that, under this potential growth assumption, the fiscal expansion could be accommodated without barely any infiationary pressure.

The evidence so far shows, howcver, that carrying out such ambitious spending plans may prove a difficult task to accotnplish, and underspending has been pervasive in recent years. For example, while spending in transfers may be implemented almost automatically, public investment plans may be delayed. Because of this uncertainty about the precise future path of the public finances, a second exercise has been performed to understand the differential effect on demand of each of the components of the fiscal stance. Concretely, in each of the exercises below, it is assumed that one of the components of spending increases by 1 percent of GDP. A fourth exercise explores the effects of a decline in revenues of the same magnitude.

\begin{tabular}{|l|rrr|rrr|rrr|rrr|}
\hline & \multicolumn{3}{|c|}{ G\&S } & \multicolumn{3}{c|}{ Investment } & \multicolumn{3}{c|}{ Transfers } & \multicolumn{3}{c|}{ Revenues } \\
\hline & 2000 & 2001 & 2000 & 2000 & 2001 & 2002 & 2000 & 2001 & 2002 & 2000 & 2001 & 2002 \\
GDP & & & & & & & & & & & & \\
RPIX Inflation & 0.2 & 0.7 & 0.4 & 0.2 & 0.8 & 0.5 & 0.1 & 0.5 & 0.3 & 0.1 & 0.5 & 0.3 \\
Nominal interest rate & 0.0 & 0.1 & 0.6 & 0.0 & 0.1 & 0.5 & 0.0 & 0.2 & 0.5 & 0.0 & 0.2 & 0.6 \\
Real exchange rate & 0.1 & 0.8 & 0.8 & 0.1 & 0.8 & 0.9 & 0.1 & 0.5 & 0.5 & 0.1 & 0.6 & 0.6 \\
Current account/GDP & -0.1 & -0.8 & -0.2 & 0.2 & 0.8 & -0.1 & 0.1 & 0.5 & -0.1 & 0.2 & 0.6 & -0.1 \\
\hline
\end{tabular}

The results show that the composition of the fiscal expansion matters: an increase in spending in goods and services and in capital goods is more expansionary than a comparable increase in transfers or a decline in revenues. In this respect, analyzing the demand impact of the fiscal stance by looking at the overall balance could lead to misleading conclusions of the type, for example, that unexpected revenue overperformance offsets a planned increase in spending on goods and services. 
United Kingdom: Basic Data

Denographic and other data:

\section{Area}

Population (mid-1999)

Infant mortality (per 1,000 live births)

Doctors per 1,000 inhabitants

GDP per capita (1999)

Composition of GDP in 1999, at current prices

Private consumption

Public consurnption

Total investment (mcluding stockbuilding)

Total domextic demand

Exporss of goods and services

Imports of goods and services

GDP at market prices (average estimate)

Selected economic data

Output and nemployment:

Real GDP (at market prices, average estimate)

Manufacturing production

Average umemployment ( Labor force survey, in percent)

Eamings and prices:

Average earnings in manufacturing

Retail price index, excluding mortgage interest

\section{Money and interest rates:}

MO (end of period)

M4 (end of period)

3-month Interbank rate

10-year goverament bond yifeld

Fiscal accounts (In pereent of GDP): 4/

General government balance

Public sector balance

Public sector net debt

Balance of payments:

Current account balance

(In percent of GDP)

Trade balance (goods)

Exports

Inports

Direct investment (net)

Portfolio investment (net)

Gross reserves,official besis

94,247 square miles $(244,100 \mathrm{sq}, \mathrm{km}$.

59.5 million

6.1

0.5

SDR 17,814

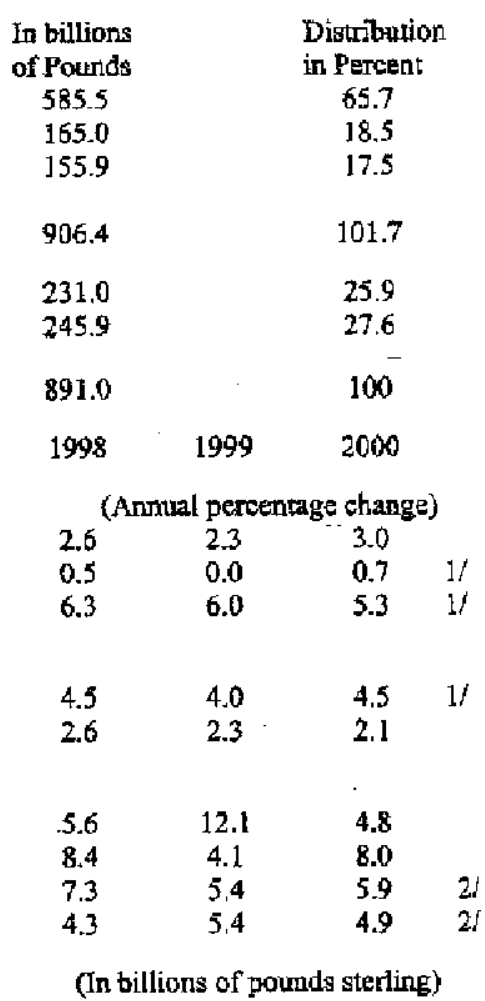

$\begin{array}{rrrr}0.7 & 1.7 & 3.6 & 4 f \\ 0.6 & 1.7 & 3.5 & 4 f \\ 40.6 & 37.6 & 33.1 & 4 l\end{array}$

$\begin{array}{rrrr}-0.1 & -9.9 & -9.9 & 5 / \\ 0.0 & -1.1 & -1.4 & 5 / \\ -20.5 & -26.2 & -25.3 & 6 / \\ 164.1 & 166.2 & 171.2 & 6 / \\ 184.6 & 192.4 & 196.5 & 6 j \\ -33.5 & -73.0 & -82.4 & 5 / \\ -18.8 & 110.2 & 74.4 & 5 / \\ 22.4 & 25.9 & 33.0 & 2 /\end{array}$

Source: Office for National Statistics; and staff estimates.

I/ Septeraber - November 2000.

2/ December 2000.

3/ Fiscal year beginning April 1.

4/ Includes 2.4 percentage points of GDP in $2000 / 01$ corresponding to the auction proceeds of spectrum licenses.

5/ January - September 2000.

6/ Janury - Novenber 2000 . 


\section{UNITED KINGDOM: Fund Relations}

(As of December 31, 2000)

I. Membership Status: Joined 12/27/1945; Article VIII

II. General Resources Account:

$$
\begin{gathered}
\text { SDR Million } \\
10,738.50 \\
7,450.56 \\
3,287.95 \\
-24.00
\end{gathered}
$$

Operational budget transfers (net)

III. SDR Department:

Net cumulative allocation

Holdings

Designation Plan

IV. Outstanding Purchases and Loans:

V. Financial Arrangements:

VI. Projected Obligations to Fund:

VII. Exchange Rate Arrangement:

On September 16, 1992, the U.K. authorities withdrew the pound sterling from the exchange rate mechanism of the European Monetary System and have since maintained a floating regime. As of January 31,2001 the exchange rate for sterling was $\$ 1.459$.

In accordance with U.N. or EU resolutions, the United Kingdom applies exchange restrictions vis-à-vis Iraq, certain assets of the Taliban, transfers to or for the benefit of UNITA, certain assets in relation to Mr. Milosevic and associates, and certain persons related to important government functions in Myanmar. These restrictions have been notified to the Fund under Decision 144-(52/51) (see EBD/90/242 in respect of Iraq, EBD/01/16 in respect of the Taliban and UNITA, and EBD/01/15 in respect to Mr. Milosevic and Myanmar).

\section{Article IV Consultation:}

Discussions for the 1999 Article IV consultation were conducted in London during November 12-22, 1999. The Staff Report (SM/00/32) was considered by the Executive Board on March 1, 2000 (EBM/00/20).

$\begin{array}{lll}\text { IX } & \text { Technical Assistance: } & \text { None } \\ \text { X. Resident Representative: } & \text { None }\end{array}$




\section{United Kingdom-Statistical Information}

The United Kingdom maintains high standards of economic data provision. The authorities publish a full range of economic and financial data that is available electronically and have subscribed to the Special Data Dissemination Standard (SDDS). The UK shifted to ESA95 in September 1997. The main statistical change was the adoption of a wider concept of capital formation, to include computer software, mineral exploration, and military dual-use assets. It also reclassified some expenditures from net investment to depreciation. Other changes included a rebasing of the constant price estimates to a price base of 1995 , a new constant price estimate of government output, and major improvements to the business register. 


\section{United Kingdom: Core Statistical Indicators}

as of January 31, 2001

\begin{tabular}{|c|c|c|c|c|c|c|c|c|c|c|c|c|}
\hline & $\begin{array}{c}\text { Exchange } \\
\text { Rates }\end{array}$ & $\begin{array}{l}\text { Internationa } \\
\text { Reserves }\end{array}$ & $\begin{array}{c}\text { Central } \\
\text { Bank } \\
\text { Balance } \\
\text { Sheet }\end{array}$ & $\begin{array}{c}\text { Reserve/ } \\
\text { Base } \\
\text { money }\end{array}$ & $\begin{array}{l}\text { Broad } \\
\text { Money }\end{array}$ & $\begin{array}{c}\text { Interest } \\
\text { Rates }\end{array}$ & $\begin{array}{l}\text { Consumer } \\
\text { Price } \\
\text { Index }\end{array}$ & $\begin{array}{l}\text { Exports/ } \\
\text { Imports }\end{array}$ & $\begin{array}{l}\text { Current } \\
\text { Account } \\
\text { Balance }\end{array}$ & $\begin{array}{l}\text { Overall } \\
\text { Govern- } \\
\text { ment } \\
\text { Balance }\end{array}$ & $\begin{array}{l}\text { GDP/ } \\
\text { GNP }\end{array}$ & $\begin{array}{c}\text { External } \\
\text { Debt' } \\
\text { Debt Service }\end{array}$ \\
\hline $\begin{array}{l}\text { Date of Latest } \\
\text { Observation }\end{array}$ & $01 / 31 / 2001$ & December & December & December & December & $01 / 31 / 2001$ & $12 / 2000$ & $11 / 2000$ & $2000 \mathrm{Q3}$ & December & $2000 \mathrm{Q}^{3}$ & 1999 \\
\hline Date Received & $01 / 31 / 2001$ & January & January & Jantary & January & $01 / 31 / 2001$ & fanizary & December & December & January & December & Sept 2000 \\
\hline $\begin{array}{l}\text { Frequency } \\
\text { of Data }\end{array}$ & Daily & Monthly & Monthly & Monthly & Monthly & Daily & Monthly & Monthly & Quartetly & Monthly & Quarterly & Anthual. \\
\hline Frequency & Daily & Monthly & Monthly & Mopthly & Monthly & Daily & Monthly & Monthly & Quarterly & Monthly & Quarterly & Annual \\
\hline Source of Update & Bloomberg & $\begin{array}{l}\text { BOE } \\
\text { TRE }\end{array}$ & $\begin{array}{l}\text { BOE } \\
\text { Press Rel. }\end{array}$ & $\begin{array}{l}\text { BOE } \\
\text { Press Rel. }\end{array}$ & $\begin{array}{l}\text { BOE } \\
\text { Press Rel. }\end{array}$ & $\begin{array}{l}\text { RES } \\
\text { Reuters } \\
\text { Bloomberg }\end{array}$ & $\begin{array}{l}\text { ONS } \\
\text { Press Rel. }\end{array}$ & $\begin{array}{l}\text { ONS } \\
\text { Press Rel. }\end{array}$ & $\begin{array}{l}\text { ONS } \\
\text { Press Rel. }\end{array}$ & $\begin{array}{l}\text { ONS } \\
\text { Press Rel. }\end{array}$ & $\begin{array}{l}\text { ONS } \\
\text { Press Rel. }\end{array}$ & ONS \\
\hline $\begin{array}{l}\text { Mode of } \\
\text { Reporting }\end{array}$ & Electronic & Electronic & \begin{tabular}{|l} 
Publica./ \\
Electronic
\end{tabular} & $\begin{array}{l}\text { Publica./ } \\
\text { Electronic }\end{array}$ & $\begin{array}{l}\text { Publica/ } \\
\text { Electronic }\end{array}$ & Electronic & Electronic & Electronic & Electronic & Electronic & Electronic & Electronic \\
\hline Confidentiality & Published & Published & Published & Published & Published & Published & Published & Published & Published & Published & Published & Published \\
\hline $\begin{array}{l}\text { Frequency of } \\
\text { Publication }\end{array}$ & Daily & Monthly & Monthly & Monthly & Monthly & Daily & Monthly & Monthly & Quarterly & Monthly & Quarterly & Annual \\
\hline
\end{tabular}




\section{Statement by the IMF Staff Representative February 23, 2001}

This statement provides information on economic and financial developments which has become available since the issuance of the staff report for the Article IV consultation (SM/01/32, 2/2/01). This information does not alter the thrust of the staff appraisal.

1. On February 8, the Monetary policy Committee (MPC) lowered the policy interest rate by 25 basis points to 53/4 percent. The quarterly Inflation Report published by the Bank of England on February 14 indicates that the MPC considered the current underlying growth rate of the economy to be close to its trend rate and the near-term outlook for growth to be somewhat softer than in the November Inflation Report. Short-term money market interest rates have continued moving downwards and the market appears to be expecting further rate cuts of about 50 basis points in 2001 .

2. The target inflation rate RPIX (which excludes mortgage interest payments) edged down to 1.8 percent in January from 2.0 percent in December partly reflecting lower prices for petrol and fuels. The harmonized index of consumer prices (HIPC) remained unchanged at 0.9 percent in January. Average earnings growth edged up slightly in December to 4.4 percent compared to 4.2 percent in November (most wage settlements will take place between January and April).

3. Regarding cyclical indicators of economic activity, the pace of manufacturing production held steady, increasing in December by 0.5 percent on a three-month basis and by 1.3 percent on a 12-month basis. Nevertheless, the production index for the overall production industries declined 0.6 percent on a three-month basis owing to a significant decline in oil and gas extraction which typically exhibits erratic behavior over short periods. Household demand remained strong with retail sales growing at 1.3 percent in the three months to January 2001 with respect to the previous three months. Unemployment remained roughly flat with the labor force survey-based unemployment rate at 5.3 percent in the three months to December and the claimant count rate at 3.5 percent in January.

4. Public sector finances data indicate that the cumulative public sector surplus for the period April 2000-January 2001 increased to $£ 16.7$ billion, compared to $£ 13.8$ billion for the same period of the previous fiscal year. This outturn was due to buoyant revenues which more than offset the spending increases being implemented in accordance with the 2000 budget plans. This would suggest that the budget surplus for fiscal year 2000/01 could not only be larger than the $£ 8.7$ billion projected in the November Pre-Budget report, but also be somewhat higher than the $£ 12$ billion projected by the staff in the staff report. 


\section{INTERNATIONAL MONETARY FUND}

Public Information Notice (PIN) No. 01/15 FOR IMMEDIATE RELEASE February 28, 2001

International Monetary Fund $70019^{\text {th }}$ Street, NW Washington, D. C. 20431 USA

\section{IMF Concludes Article IV Consultation with the United Kingdom}

On February 23, 2001, the Executive Board of the International Monetary Fund (IMF) concluded the Article IV consultation with the United Kingdom. ${ }^{1}$

\section{Background}

The United Kingdom is experiencing the longest period of sustained noninflationary output growth in more than 30 years. Output growth has averaged 2.9 percent in 19932000 , the rate of unemployment is at its lowest level in a quarter century, and inflation has remained at or below 3 percent. Long-term interest rates have declined markedly and private investment has increased reflecting declining risk premia and improved business confidence. These developments have been accompanied by substantial changes in fiscal and monetary policy. The fiscal position tightened significantly with the structural balance improving by almost 9 percentage points of GDP since 1992 and the net public debt declining by more than 12 percentage points of GDP to about 33 percent at end-2000. The authorities adopted inflation targeting in 1992 and granted operational independence to the Bank of England in 1997, with the primary objective of maintaining price stability, defined by an inflation target of $2 \frac{1}{2}$ percent.

Notwithstanding these achievements, the productivity performance of the United Kingdom has been weak in comparison with other industrialized countries: labor productivity in manufacturing declined on average 0.3 percent annually in 1995-1998. This performance can be attributed to past low public and private investment in physical capital and to low total factor productivity growth which partly reflects skill deficiencies in the labor force. In the past year and a half, however, overall-economy productivity growth has accelerated, led by strong-albeit still uneven—gains in manufacturing,

'Under Article IV of the IMF's Articles of Agreement, the IMF holds bilateral discussions with members, usually every year. A staff team visits the country, collects economic and financial information, and discusses with officials the country's economic developments and policies. On return to headquarters, the staff prepares a report, which forms the basis for discussion by the Executive Board. At the conclusion of the discussion, the Managing Director, as Chairman of the Board, summarizes the views of Executive Directors, and this summary is transmitted to the country's authorities. This PIN summarizes the views of the Executive Board as expressed during the February 23, 2001 Executive Board discussion based on the staff report. 
notably in information and communication technology (ICT) industries, and ICT-intensive services, sparking interest in possible "New Economy" effects.

Output growth in 2000 is estimated at around 3 percent reflecting buoyant domestic demand. Private consumption growth remained strong, underpinned by continued employment gains over several years and sizable increases in earnings, disposable income, and wealth through early-2000. Investment weakened after several years of growth, although it remains at high levels in real terms as a share of GDP. Rising external demand in 2000 improved export performance substantially, but imports aiso grew rapidly and the current account continued to exert a drag on growth reflecting the strength of sterling. Inflation remained subdued, with the targeted rate (RPIX) hovering around 2 percent. The unemployment rate fell further to 5.3 percent (on a labor force survey basis) while earnings growth moderated to below $4 \frac{1}{2}$ percent by year end.

The $1999 / 00$ budget closed with a public sector surplus of 1.7 percent of GDP (on an ESA95 basis), a substantial overperformance relative to the original budget plan of a deficit of 0.5 percent of GDP. Budgetary policies formulated in 2000 envisage sizable spending increases extending over 2001 and beyond-mainly on infrastructure investment, health, education, and social services - as well as targeted tax cuts. The November 2000 Pre-Budget Report introduced, among other measures, a generous pensioner benefits package and a fuel tax freeze while a possible fuel tax cut was proposed for consultation. These would lower the overall surplus from 1.7 percent of GDP in 1999/00 to under 1/2 percent of GDP in 2001/02 and to a deficit of about 1 percent of GDP by $2003 / 04$ on the Government's projections. A fiscal overperformance is likely in 2000/01 as revenue remains buoyant due to improvements in tax administration and there appear to be delays in implementing spending increases.

The Bank of England kept policy rates unchanged at 6 percent from February 2000 to January 2001 following a 100 basis point tightening cycle that started the previous summer. Continued moderation in wage and inflation pressures, and indications that factors underpinning private demand-such as assets and housing prices and surveys of investment intentions-were plateauing or weakening argued against an increase, even if household consumption and credit remained strong. As concems over possible inflation pressures and overheating gradually dissipated through the second half of 2000 , market expectations of further policy rate hikes faded (turning into expectations of future rate cuts) and short- and medium-term market rates shifted downwards-easing monetary conditions over the year. In February 2001, the Monetary Policy Committee lowered the policy rate by 25 basis points to $5 \frac{3}{4}$ percent to forestall a weakening in economic activity, mainly on account of a deterioration in the external outlook.

\section{Executive Board Assessment}

Executive Directors commended the authorities for the continued strong performance of the U.K. economy since the early 1990s, a performance that marks the longest period of sustained output and employment growth and low inflation in more than 30 years. They agreed that sound fiscal and monetary policies, underpinned by transparent mediumterm policy frameworks as well as sustained implementation of structural reforms, have 
contributed to these achievements. They noted that, after maintaining a brisk pace for most of last year, output growth appears to have slowed to around trend, with inflation remaining subdued and few signs of significant imbalances. At the same time, a number of Directors expressed concern about the high real exchange rate, underscoring the need for the authorities to remain alert to the implications for competitiveness and the policy mix.

Looking forward, Directors expected that output growth would remain robust, with a substantial increase in public spending from measures announced in last year's budget offsetting slower private consumption growth. With risks of further downward adjustment to global growth and equity prices, they observed that the risks to the outlook appear, on balance, to be tilted to the downside, although consumer confidence and private consumption growth remain buoyant. Directors agreed that prospects for inflation remain benign, given the strong sterling and subdued wage growth so far.

Directors observed that the challenge in the short term is to sustain the economic expansion through an appropriate macroeconomic policy mix. Given the continued favorable prospects for price stability, they welcomed the recent cut in the policy rate by the Bank of England. Directors expressed their appreciation for the authorities' demonstrated readiness to respond Judiciously to changes in the inflation outlook, and encouraged them to stand ready to cut the policy rate further if signs of weakening domestic activity emerge and wage pressures remain moderate.

Directors noted that, even after taking into account recent spending decisions, the fiscal position remains sound and fully consistent with the authorities' medium-term fiscal framework. They considered that the authorities' investment plans would improve the U.K.'s competitiveness and its attractiveness for investors. Directors also welcomed the likely strong overperformance on last year's budget. While Directors expressed a variety of views on the short-term fiscal policy stance, on balance, many of them underscored that it would be prudent to abstain from introducing significant new spending commitments or tax cuts in the March 2001 budget. They noted that the budget measures in 2000 had already introduced significant spending increases that are now coming on stream and will result in a sizable fiscal impulse this year. These Directors also cautioned that additional fiscal stimulus would limit the room for further interest rate cuts, and, at a time when interest rates might decline elsewhere, this would tend to cause further upward pressure on sterling. Other Directors, however, noted that the course of the exchange rate in response to a fiscal expansion is hard to predict.

Directors welcomed the priority that the authorities are placing on boosting the productivity performance of the U.K. economy over the medium term. They broadly supported their approach to this issue, agreeing that macroeconomic stability and strong policy frameworks are likely to contribute to maintaining the current high levels of investment and enhancing growth prospects. Directors also agreed that plans to increase public investment in infrastructure and human capital are justified in light of the evidence that past underinvestment in these areas has been a factor underlying the United Kingdom's comparatively weak productivity performance. 
Directors considered the authorities' mediurn-term fiscal strategy to be broadly appropriate. At the same time, many Directors suggested that there may be scope for the public sector to play a more ambitious role in promoting national saving and investment. More specifically, they considered that it would be preferable to fund all public investment through higher public saving, i.e., to maintain a surplus or broad overall balance over the cycle, as is now the case. These Directors stressed that this objective could be achieved within the existing three-year spending plans by saving the likely revenue overperformance over the coming years.

Directors also broadly endorsed the authorities' approach to boosting productivity by aiming microeconomic reforms and structural policies at identified market failures, such as the difficulty of financing private research and development activity. They welcomed the authorities' efforts to enhance competition, innovation, and entrepreneurship, in view of the need both to foster the New Economy and boost productivity growth in the rest of the economy. Directors encouraged the authorities to implement promptly the Competition Act and welcomed the strengthening of the powers of the Office of Fair Trading.

Directors commended the authorities for a decade and a half of labor market reforms which have underpinned the remarkable achievements with regard to the expansion of employment and reduction in unemployment. Although the authorities' objective of achieving high levels of employment is being met, employment rates among specific groups such as young, low-skilled men remain an area of concern. Directors therefore agreed that the priorities are to increase the incentives of such groups to work and close the skill gaps between the U.K. workforce and those of other major industrial countries. In this connection, Directors observed that the New Deal programs appear to be working well on the whole. However, they saw room for tapering unemployment benefits in a manner that increases disincentives to remain unemployed for long periods, and for linking unemployment and welfare benefits more closely with job search. The introduction of the National Minimum Wage (NMW) appears to have had little adverse impact on employment and inflation, but Directors cautioned against significant increases in the NMW or raising the youth minimum wage rate to a level of the NMW.

Directors welcomed the progress in implementing pension reform and noted that the experience under stakeholder pensions bears watching for lessons that could be learned on private pension provision for lower income groups. They also cautioned against further public pension-related commitments-particularly those indexed to earnings in future budgets-given the implications for long-term public liabilities.

Directors also welcomed the progress in consolidating the role of the Financial Services Authority (FSA) as the single financial system regulator, and noted that the U.K. banking system is profitable and well capitalized. They encouraged the authorities to remain vigilant in the somewhat riskier environment in the period ahead, particularly if possible global financial market weakness were to feed into domestic market confidence. In this regard, they noted that the concentration of banks' exposures to specific risks, such as 
the telecommunications sector, deserves close monitoring as the FSA is already doing. Directors welcomed the United Kingdom's intention to participate in an FSAP.

Directors considered that the decision to join EMU remains a key medium-term issue for the United Kingdom and concurred that the five tests or criteria established by the authorities reflect the economic considerations central to this decision. With regard to the criterion of sustained convergence, a few Directors observed that recent experience suggests that cyclical synchronization between the United Kingdom and the euro area appears to be increasing.

Directors praised the authorities' initiative to relieve the debt burden of the poorest countries, including through the full bilateral debt write-off in the context of the HIPC Initiative as well as their commitment to raise official development assistance over the next three years. They encouraged the authorities to accelerate progress toward the U.N. target for overseas assistance of 0.7 percent of GNP. Directors also welcomed the authorities' support for the European Commission's proposal to grant duty and quotafree access for exports from least developed countries.

The United Kingdom publishes data on a sufficiently timely and comprehensive basis to permit effective surveillance.

Public Information Notices (PINs) are issued, (i) at the request of a member country, following the conclusion of the Article IV consultation for countries seeking to make known the views of the IMF to the public. This action is intended to strengthen IMF surveillance over the economic policies of member countries by increasing the transparency of the IMF's assessment of these policies; and (ii) following policy discussions in the Executive Board at the decision of the Board. 
Table 1 : Selected Economic Indicators

\begin{tabular}{|c|c|c|c|c|c|c|}
\hline & 1996 & 1997 & 1998 & 1999 & $20001 /$ & 200111 \\
\hline \multicolumn{7}{|l|}{ Real Economy (change in percent) } \\
\hline Real GDP & 2.6 & 3.5 & 2.6 & 2.3 & 3.0 & 2.7 \\
\hline Domestic demand & 3.0 & 3.8 & 4.6 & 3.8 & 3.9 & 3.4 \\
\hline $\mathrm{CPI}$ (excluding mortgage interest) & 3.0 & 2.8 & 2.7 & 2.3 & 2.1 & 2.5 \\
\hline Unemployment rate $(\mid \mathrm{n}$ percent $\} \quad 2 /$ & 8.1 & 7.0 & 6.3 & 6.0 & $5.33 /$ & $\ldots$ \\
\hline Gross national saving (percent of GDP) & 16.8 & 18.0 & 17.9 & 16.4 & 16.4 & 16.2 \\
\hline Gross domestic investment (percent of GDP) & 16.9 & 17.2 & 17.9 & 17.5 & 17.8 & 18.1 \\
\hline \multicolumn{7}{|l|}{ Public Finance (in percent of fiscal year GDP) 4/ } \\
\hline General government balance & -3.8 & -0.7 & 0.7 & 1.7 & $3.65 /$ & 0.5 \\
\hline Public sector balance & -3.6 & -0.7 & 0.6 & 1.7 & $3.55 /$ & 0.4 \\
\hline Public sector structural balance & -3.0 & -0.3 & 0.6 & 1.7 & 1.1 & 0.4 \\
\hline General government gross debt & 52.2 & 49.2 & 46.5 & 43.6 & 40.2 & 37.4 \\
\hline Public sector net debt & 45.4 & 43.2 & 40.6 & 37.6 & 33.1 & 31.3 \\
\hline \multicolumn{7}{|l|}{ Money and Credit (end-year, percent change) } \\
\hline мá & 6.6 & 6.3 & 5.8 & 11.7 & 4.8 & $\ldots$ \\
\hline M4 & 9.5 & 5.7 & 8.3 & 4.1 & 8.0 & $\ldots$ \\
\hline Consumer Credit & 13.6 & 13.8 & 16.2 & 13.0 & 16.0 & $\cdots$ \\
\hline \multicolumn{7}{|l|}{ Interest rates (year average) } \\
\hline Three-month interbank rate & 6.0 & 6.9 & 7.4 & 5.3 & 5.961 & $\ldots$ \\
\hline Ten-year Government bond yield & 7.8 & 7.0 & 5.5 & 5.4 & 4.961 & $\ldots$ \\
\hline \multicolumn{7}{|l|}{ Balance of Payments } \\
\hline Trade balance (goods, in percent of GDP) & -1.7 & -1.5 & $-2,4$ & -2.9 & -3.1 & -3.8 \\
\hline Current account (in percent of GDP) & -0.1 & 0.8 & 0.0 & -1.1 & -1.4 & -1.9 \\
\hline $\begin{array}{l}\text { Reserves (national valuation of goid, } \\
\text { end of period, in billicns of SDRs) }\end{array}$ & 31.6 & 27.5 & 26.5 & 30.5 & 36.9 & $\ldots$ \\
\hline Reserves cover (months of imports of goods and services) & 1.1 & 0.9 & 0.8 & 0.9 & 1.1 & $\cdots$ \\
\hline \multicolumn{7}{|l|}{ Fund Position (As of December 31, 2000) } \\
\hline Holdings of currency (in percent of quota) & & & & & 69.4 & \\
\hline Holdings of SDRs (in percent of allocation) & & & & & 13.1 & \\
\hline Quota (in millions of SDRs) & & & & & $10,738,5$ & \\
\hline \multicolumn{7}{|l|}{ Exchange Rate } \\
\hline Exchange rate regime & \multirow{2}{*}{\multicolumn{3}{|c|}{$\begin{array}{l}\text { Floating exchange rate } \\
\text { US } \$ 1=£ 0.685\end{array}$}} & & & \\
\hline Present rate (January 31, 2001) & & & & & & \\
\hline Nominal effective rate $(1995=100)$ & 101.7 & 118.5 & 122.5 & 122.3 & 126.7 & $\ldots$ \\
\hline Real effective rate $(1995=100) 7 /$ & 102.4 & 124.6 & 137.3 & 142.4 & 154.4 & $\ldots$ \\
\hline
\end{tabular}

Source: National Statistics; HM Treasury; Bank of England; IMF, International Financial"Statistics; INS; and staff estimates.

1/ Staff projections, except where noted.

2/ Labor force survey basis.

3/ September - November 2000.

4/ Fiscal year beginning April 1.

$5 /$ Includes 2.4 percentage points of GDP in 2000/01 corresponding to the auction proceeds of spectrum licenses.

6/ December 2000.

7) Based on relative normalized unit labor costs in manufacturing. 


\section{Statement by Stephen Pickford, Executive Director \\ for the United Kingdom \\ February 23, 2001}

1. Let me begin by expressing my authorities' appreciation for the efforts of Jacques Artus and his team. As always, they have produced an extremely interesting report, which will be a useful contribution to the public debate about economic policy and priorities.

\section{Recent developments and prospects}

2. The UK economy continues to enjoy sustained positive growth, with low and stable inflation and falling unemployment. A year ago, both staff and my authorities were forecasting robust growth for 2000 in the range $2^{3 / 4}$ to $31 / 4$ percent. Our latest official projection in November was for growth of around 3 percent. Since then, preliminary data for the fourth quarter of 2000 suggest growth slowed a little towards the end of last year, but this was mainly due to a large fall in the volatile oil and gas sector. Confidence indicators remain high, although, if the external environment deteriorates significantly, there will be implications for UK growth.

3. Strong export growth last year contributed to a much stronger net trade performance compared to previous years. Although imports also grew strongly, the current account deficit has levelled at around 11/4 per cent of GDP. Manufacturing output growth of 1.6 per cent in 2000 was the highest since 1994, but variation in performance within the sector remains marked and the sector overall continues to lag the much stronger expansion in services.

4. Further gains in employment last year took unemployment to its lowest level since the 1970 s, ending 2000 at 5.3 per cent an the ILO-consistent measure and just 3.5 per cent on the claimant count basis. However, despite labour market tightening and some signs of skills shortages starting to emerge, growth in average earnings remained moderate at a little under $4 \frac{1}{2}$ per cent in the fourth quarter of 2000 . Productivity growth rose to 2.6 per cent in the year to $2000 \mathrm{Q3}$, a considerable improvement over previous years, and helped to hold down unit labour costs. RPLX inflation averaged just 2.1 per cent in 2000 , the lowest since the current series began in 1976, notwithstanding the sharp rise in oil prices during last year.

5. In recent months there has been a shift in the balance of risks to the UK's economic prospects, reflecting weaker inflationary pressure in the UK and, in particular, the possibility of a further slowdown in the US. In response to these concerns the Bank of England's Monetary Policy Committee (MPC) pre-emptively reduced interest rates by 25 basis points to $53 / 4$ per cent on 8 February. Since then, inflation figures for January showed underlying inflation falling to 1.8 per cent. 


\section{Policy framework}

6. The Government has put in place a macroeconomic framework based on the principles of transparency, responsibility and accountability to deliver economic stability for the long term. The monetary policy framework aims to deliver low and stable inflation, with the MPC setting the Bank of England's policy rate to meet the Government's inflation target. The fiscal policy framework is geared to ensuring, over the medium term, sound public finances and spending and taxation policies which are equitable both within and across generations; and, over the short term, to support monetary policy, in particulat by allowing the automatic stabilizers to play their role in smoothing the path of the economy. The Government has set two fiscal rules: the golden rule - over the cycle, the government will borrow only to invest and not to fund current spending; and the sustainable investment rule public sector net debt as a proportion of GDP will be held over the economic cycle at a stable and prudent level.

7. My authorities' position on EMU remains unchanged. Any government decision on EMU entry will be determined by whether the economic case for the UK of joining is clear and unambiguous, based on the five economic tests. The Government has said that an assessment of the five tests will be carried out early in the next Parliament.

\section{Short-term issues}

8. Looking forward, there continues to be little difference between the staff and my authorities on the prospects for the UK economy. The latest official forecast, prepared last November, was for growth this year of $2 \frac{1 / 4}{4}$ to $23 / 4$ percent. The staff forecast is at the top end of that range. Updated forecasts will be presented in the Budget on $7 \mathrm{March}$.

9. In last year's report, staff said that the "March 2000 Budget should not use the margins built up by the over-performance of the previous year and instead aim to keep the structural fiscal balance unchanged". The November Pre-Budget Report expected a cyclically-adjusted surplus for Public Sector Net Borrowing (PSNB) in 2000-01 which was 0.3 percentage points larger than projected in Budget 2000 , which itself projected a 0.3 percentage points tighter position in 2000-01 than anticipated in the previous Budget. So the likely outturn for 200001 is for a much tighter fiscal stance than most -- including staff -- expected. This has contributed to a lowering of interest rate expectations, and will have beneficial effects on activity and inflation through 2001-02.

10. Again in this year's report, staff have argued that the fiscal stance in the forthcoming Budget should be at least as tight as last year to avoid burdening monetary policy. My authorities believe that staff fears of inflationary pressures in the economy from the planned expansion in public spending during 2001-02 are not well-founded. The November PreBudget Report projected an on-going structural surplus in 2001-02. Moreover, the fiscal framework in the UK, based on prudence and caution, has restored the public finances to a healthy and sustainable position which has resulted in a decline in the ratio of net debt to 
GDP from 44 per cent in 1996-97 to a little over 30 per cent now. The sustained improvement has helped make possible the large investment in public services that was announced in last summer's Spending Review 2000, while also supporting monetary policy in the short term. The government has increased investment in key priorities such as health, education and transport, thereby addressing years of under-investment in the public sector, which staff agree is necessary. Staff also concur that the planned move from surplus to small deficit consistent with our fiscal framework and our two fiscal rules does not threaten medium-term sustainability of the public finances.

11. Meeting the inflation target is the job of monetary policy. The MPC had raised interest rates to 6 per cent in February 2000 , but then left rates unchanged throughout the rest of the year as consistent with achieving the inflation target, taking full account of the public spending plans set out in the Budget and Spending Review 2000. Indeed, as the report highlights, by the end of 2000 the balance of the debate on the MPC had shifted to whether the policy stance should be eased. Interest rates were then cut by 25 basis points two weeks ago on the basis of the expected effect of weaker prospects for the US economy coupled with the fact that price and cost pressures in the UK have remained benign. The MPC's view is that the risks to growth and inflation are clearly on the downside of the central projection published in the February Inflation Report. That central projection implied that the planned increase in public expenditure was consistent with meeting the inflation target.

12. Staff have also argued that, if domestic private spending and external demand remain strong, the planned public spending increases would contribute to pressure for an interest rate increase and possible further real appreciation of sterling. My authorities are not convinced that a short-term and temporary shift in the balance between monetary and fiscal policy would have a significant and predictable effect on the exchange rate, given that the appreciation in the real exchange rate since 1996 coincided with a tightening of the fiscal stance totalling almost 5 per cent of GDP.

\section{Medium-term issues}

13. Staff argue in the report that, given the degree of caution built into the public finance projections, it would be better to fund public investment in the UK through offsetting measures on current spending or revenue rather than through borrowing, preferring a broadly balanced budget over the cycle instead of the golden rule. However, the golden rule supports intergenerational fairness by helping to ensure future generations contribute to the costs of today's investment where benefits accrue to them in the future. Current spending is at least matched by current receipts over the cycle. Sound public finances are also assured by the sustainable investment rule. The Pre-Budget Report projects public sector net debt falling to around 30 per cent in 2001-02, which is amongst the lowest in the EU and G7.

14. Moreover, my authorities strongly believe that in order to meet the fiscal rules there is no room for complacency. Hence, the public finance projections are based on prudent and 
cautious assumptions. For example, the public finance projections are based on an assumed growth in potential output of just $2 \frac{1 / 4}{4}$ per cent.

15. My authorities agree with the staff's assessment that more public spending is required on priority areas - health, education, and public infrastructure -- while maintaining a sound overall fiscal position. Increased spending on these priorities was announced in last summer's Spending Review. Over the next three years net investment is planned to more than double, rising to a share of 1.8 per cent of GDP by $2003-04$. An annual $£ 43$ billion of additional funding has been allocated for significant improvements in key public services by the end of this period. The priority areas of education, health, transport and housing and law and order will account for more than three-quarters of the rise in spending.

16. As the staff point out, the UK's long-term record on productivity growth has over decades been disappointing. The productivity gap between the UK and its major competitors is substantial and longstanding. My authorities recognize that improving productivity performance is key to achieving higher long-term growth and sustained increases in living standards. My authorities are therefore committed to improving productivity performance and have put in place a long-term strategy built around macroeconomic stability and microeconomic reforms targeted at market failures, with a focus on five priority areas:

- promoting competition and better regulation;

- encouraging enterprise and innovation;

- raising investment;

- improving skills levels; and

- raising public sector productivity

17. The staff investigation into whether the UK is beginning to benefit from the "new economy" is welcome and timely. This issue is the focus also of much research in the UK. There have been large investments in ICT in the UK over recent years, and there is some evidence of productivity increasing in the ICT sector. However, whole economy productivity growth was, on average, relatively weak through the second half of the 1990 s as a result of muted gains between 1995 and 1999. So, while productivity growth has picked up significantly since then, and we think there are good reasons to be optimistic about future improvements, we do not believe it is prudent at this stage to build significant improvements in productivity growth into our forecasts.

18. My authorities welcome the staff's positive comments on our pension reforms, particularly in recognising the balance that needs to be struck between improving savings incentives for the current generation of workers, especially for low income groups, whilst reducing poverty amongst current pensioners. As with our general approach to fiscal policy, my authorities have been determined to ensure the UK pension system is built on a prudent and sustainable basis. 


\section{Financial issues}

19. When the Financial Services and Markets Act (FSMA) 2000 is implemented in the second half of 2001, it will provide the legal underpinning for the Financial Services Authority (FSA) as the single regulator for financial services in the UK. The new legislation will allow the FSA to move to an integrated and more transparent approach to regulation, taking into account the principles of good regulation and based on an assessment of the risks to its statutory objectives:

- maintaining confidence in the UK financial system;

- promoting public understanding of the UK financial system;

- securing an appropriate degree of protection for consumers; and

- reducing the scope for financial crime. .

20. The UK has been active on the international front in a variety of ways. It is an active member of the Basle Committee on Banking Supervision (BCBS), the Basle Committee on Payment and Settlement Systems (CPSS), the International Association of Insurance Supervisors (IAIS), and the International Organisation of Securities Commissions (IOSCO), it has followed-up work on incentives for implementing international codes and standards of regulation and has participated in the Financial Action Task Force's (FATF) exercise to identify those countries and territories considered to be uncooperative in the global fight against money laundering. On the domestic front, the FSA works, along with other Government departments, to ensure that the recommendations of the review on financial regulation in the UK's Overseas Territories are implemented fully.

21. Finally, the Chancellor of the Exchequer has committed the UK to undergo an IMF Financial Sector Assessment Program (FSAP) assessment. This detailed examination of the stability of the UK financial system and the UK's adherence to internationally accepted financial sector codes and standards will be conducted by an IMF team after the FSMA has been in force for several months.

\section{Conclusion}

22. The benefits for the UK economy from the comprehensive program of enhancements to the framework for policy-making introduced in recent years are starting to be seen in sustained macroeconomic stability and better economic performance. A sound and sustainable fiscal position, coupled with a credible and effective framework for monetary policy, are setting the environment in which the private sector can take decisions with more confidence and the necessary improvements in public services can be afforded.

23. The challenge remains, however, to move to a significantly higher level of sustainable growth, the benefits of which are widely spread through the domestic economy, and which allows the UK to play a full part in maintaining a healthy world economy. 